\title{
The neurokinin-1 receptor antagonist aprepitant is a promising candidate for the treatment of breast cancer
}

\author{
MIGUEL MUÑOZ ${ }^{1}$, ANA GONZÁLEZ-ORTEGA ${ }^{1}$, MANUEL VICENTE SALINAS-MARTÍN ${ }^{2}$, \\ ANDRÉS CARRANZA ${ }^{1}$, SUSANA GARCIA-RECIO ${ }^{3-5}$, VANESSA ALMENDRO ${ }^{3-5}$ and RAFAEL COVEÑAS ${ }^{6}$ \\ ${ }^{1}$ Virgen del Rocío University Hospital, Research Laboratory on Neuropeptides, Sevilla; \\ ${ }^{2}$ Deparment of Pathology, Juan Ramón Jiménez Hospital, Huelva; ${ }^{3}$ Department of Medical Oncology, \\ Hospital Clinic, University of Barcelona; ${ }^{4}$ Institut d'Investigacions Biomediques August Pi i Sunyer; \\ ${ }^{5}$ Department of Medicine, University of Barcelona, Barcelona; ${ }^{6}$ Institute of Neurosciences of Castilla y León \\ (INCYL), Laboratory of Neuroanatomy of the Peptidergic Systems (Lab. 14), Salamanca, Spain
}

Received May 12, 2014; Accepted June 30, 2014

DOI: 10.3892/ijo.2014.2565

\begin{abstract}
The substance P (SP)/neurokinin (NK)-1 receptor system plays an important role in the development of cancer. No in-depth studies of the involvement of this system in breast cancer (BC) have been carried out, and the action exerted by the drug aprepitant on BC cells is currently unknown. We show the involvement of this system in human $\mathrm{BC}$ cell lines: i) these cells express mRNA for the NK-1 receptor; ii) they overexpress NK-1 receptors; iii) the NK-1 receptor is involved in their viability; iv) SP induces their proliferation; v) NK-1 receptor antagonists block SP-induced mitogen stimulation of these cells; vi) the specific antitumor action of such antagonists on these cells occurs through the NK-1 receptor; and vii) BC cell death is due to apoptosis. We also found NK-1 receptors and SP in all human BC samples studied. The NK-1 receptor may be a promising target in the treatment of $\mathrm{BC}$ and NK-1 receptor antagonists could be candidates as a new antitumor drug in the treatment of BC.
\end{abstract}

\section{Introduction}

Breast cancer (BC) is the most frequently diagnosed cancer and the leading cause of cancer death among females, accounting for $23 \%$ ( 1.38 million) of the total new cancer cases and $14 \%(458,400)$ of all cancer deaths in 2008 (1). The last two decades have seen no significant progress in extending the survival of patients with $\mathrm{BC}$, despite multiple

Correspondence to: Dr Miguel Muñoz, Hospital Infantil Virgen del Rocío, Unidad de Cuidados Intensivos Pediátricos, Av. Manuel Siurot s/n, 41013 Sevilla, Spain

E-mail:mmunoz@cica.es

Key words: antitumor, apoptosis, human breast cancer cell lines, L-732,138; L-733,060, NK-1 receptor antagonist trials of cytotoxic chemotherapeutic agents. Thus, there is an urgent need to improve therapy in BC patients.

In recent years the expression and secretion of peptides by tumors has gained increasing interest since these substances have been shown to influence tumor proliferation and progression (2-8). In this sense, many authors have suggested that the substance P (SP)/neurokinin (NK)-1 receptor system would play an important role in the development of cancer (2-22). SP shows a widespread distribution in both the central and peripheral nervous systems; it is released from primary sensory nerve fibers, and the NK-1 receptor shows a preferential affinity for SP (2-4). It has been suggested that SP and the NK-1 receptor would be involved in regional blockade and $\mathrm{BC}$ recurrence (5) and it has recently been demonstrated that the NK-1 receptor is involved in the viability of tumor cells $(16,23,24)$. It is also known that activation of the NK-1 receptor by SP induces mitogenesis in tumor cells; that SP is a major mediator of the growth of capillary vessels in vivo and of the proliferation of cultured endothelial cells in vitro; that NK-1 receptor agonists induce neoangiogenesis; that the migration of human breast carcinoma cells (MDA-MB-468), a crucial requirement for invasion and metastasis development, is regulated by SP; and that NK-1 receptor antagonists exert antitumor action $(2,3,10,11,13,14,16-28)$. Thus, NK-1 receptor antagonists represent an important opportunity to further exploit compounds that are active against the NK-1 receptor as novel therapeutic agents in cancer. It has recently been demonstrated that, one of them, the drug 5-[[(2R,3S)-2-[(1R)-1-[3,5-bis(trifluoromethyl) phenyl] ethoxy]-3-(4-fluorophenyl) -4-morpholinyl]methyl]1,2-dihydro-3 $H$-1,2,4-triazol-3-one (aprepitant, EMEND or MK-869), exerts antitumor activity against many human cancer cell lines and that aprepitant (Fig. 1) induces death of tumor cells by apoptosis (20). It has also been suggested that pretreatment with aprepitant prior to surgical intervention in $\mathrm{BC}$ was able to inhibit the migration of tumor cells (5). Thus, aprepitant is an excellent candidate for testing in human trials since it has already been tested (for activity and safety); it is currently used in clinical practice for emesis, and it is well tolerated (29). In addition, the lack of toxicity of aprepitant 
against normal cells (e.g., fibroblasts) has been reported: the $\mathrm{IC}_{50}$ for these cells was found to be $\sim 2$-fold higher than the $\mathrm{IC}_{50}$ for tumor cells (8).

Currently, there are data suggesting the involvement of the SP/NK-1 receptor system in BC. It has been described that $\mathrm{BC}$ cell lines and samples overexpress NK-1 receptors; that these receptors are present in the plasma membrane and/or cytoplasm of BC cells; that the inhibition of SP with antibodies inhibit cell growth and induce apoptosis in BC cell lines; that $\mathrm{BC}$ cell lines and samples show increased expression of preprotachykinin-I; that $\mathrm{BC}$ cells produce SP (demonstrated by ELISA tests); that SP stimulates BC cell proliferation; that NK-1 receptor antagonists (SR-140,333; CP-96,345, CP-99,994, MEN-11,467) reduce BC cell line (e.g., T47D, BT-474, MDA-MB330, MDA-MB231, DU4475) proliferation; that T47D cells die by apoptosis after the administration of SR-140,333; that NK-1 receptor antagonists inhibit BC cell migration, and that in vivo the NK-1 receptor antagonist MEN-11,465 controls the growth of breast carcinoma $(9-11,24,26)$. However, in none of the studies reported above was the action of the drug aprepitant studied. Thus, to date the antitumor action of aprepitant on BC is unknown (20). Moreover, there are several unknown issues in the involvement of the SP/NK-1 receptor system in BC. For example, the presence or not of NK-1 receptors in the nucleus of BC cells, the presence and localization (e.g., in the nucleus) of SP in BC samples as demonstrated by immunohistochemistry; the involvement of the NK-1 receptor in the viability of BC cells by using a small interfering RNA gene silencing method, the antitumor action (total or partial) of other NK-1 receptor antagonists hitherto not tested against BC cells [e.g., 3, 5-bis (trifluoromethyl) benzyl ester (L-732,138)] (Fig. 1). This NK-1 receptor antagonist has been previously reported to totally inhibit tumor cell proliferation $(2,3)$.

Thus, to our knowledge, there remain many unknown issues regarding the involvement of the SP/NK-1R system in $\mathrm{BC}$ and no study has been carried out previously on the antitumor action of the drug aprepitant against BC cells. Accordingly, in order to answer all the above questions, we selected three BC cell lines previously studied partially by other authors (BT-474, MCF-7 and MDA-MB-468) and another (MT-3) in which the involvement of the SP/NK-1 receptor system is studied here for the first time. The aims of this study were to demonstrate in the four BC cell lines mentioned: i) the presence of $\mathrm{NK}-1$ receptors and their isoforms; ii) mRNA expression for the NK-1 receptor; iii) the overexpression of the NK-1 receptor; iv) the involvement of the NK-1 receptor in cell viability; v) that SP induces $\mathrm{BC}$ cell proliferation; vi) that $\mathrm{NK}-1$ receptor antagonists not studied previously in BC (the drug aprepitant and L-732,138) totally inhibit the growth of these $\mathrm{BC}$ cell lines; vi) that this antitumor action occurs through the NK-1 receptor; and vii) to determine whether the three NK-1 receptor antagonists produces apoptosis in the BC cell lines studied or not. Moreover, the presence and distribution of NK-1 receptors and SP in several human BC samples were studied. We report sufficient data to suggest that the NK-1 receptor could be a promising target in human BC treatment and that the NK-1 receptor antagonist, aprepitant, should be designed as a novel therapeutic agent in $\mathrm{BC}$.

\section{Materials and methods}

Cell cultures. We used the human BC cell lines MT-3, MCF-7, MDA-MB-468 and BT-474 (DSMZ - Deutsche Sammlung von Mikroorganismen und Zellkulturen, Braunschweig, Germany and ICLC - Interlab Cell Line Collection, Genova, Italy). These cell lines were maintained in RPMI-1640 or D-MEM (Gibco, Barcelona, Spain) supplemented with 10 or $20 \%$ heat-inactivated fetal bovine serum according to the culture conditions suggested by DSMZ and ICLC. The immortalized breast epithelium MCF-10A and MCF-12A cell lines were obtained from American Type Culture Collection (Rockville, MD, USA) and cultured according to their instructions. Cell lines were seeded in $75 \mathrm{~cm}^{2}$ tissue culture flasks (Falcon, Heidelberg, Germany). The medium was renewed every 2 days and the cells were harvested by treatment with trypsin $(0.05$ and $0.02 \%$ EDTA without $\mathrm{Ca}^{2+}$ and $\mathrm{Mg}^{2+}$, Sigma-Aldrich, Madrid, Spain) on the sixth day after seeding. Cells were incubated at $37^{\circ} \mathrm{C}$ in a humidified atmosphere of $95 \%$ air $/ 5 \% \mathrm{CO}_{2}$.

Drug treatments. Three different NK-1 receptor antagonists were used in this study: L-733,060 (MW 438.9, Sigma-Aldrich; L-732,138 (MW 472.39, Sigma-Aldrich); and aprepitant (MW 534.43, the drug was kindly supplied by Merck Research Laboratories, Madrid, Spain). L-732,138 and L-733,060 were dissolved in distilled water containing $0.2 \%$ dimethylsulphoxide (DMSO) and aprepitant was dissolved in distilled water containing acetonitrile before sample treatment. In order to determine the $\mathrm{IC}_{50}$, different concentrations $(2.5-30 \mu \mathrm{M})$ of L-733,060; (5-60 $\mu \mathrm{M})$ of L-732,138 and (10-60 $\mu \mathrm{M})$ of aprepitant were evaluated for BC cell lines. SP, acetate salt (Sigma-Aldrich), was dissolved in distilled water and different concentrations $(1,5,10$ and $100 \mathrm{nM})$ were used. The most mitogenic nanomolar SP concentration for each cell line was incubated for $1 \mathrm{~h}$ before the addition of each NK-1 receptor antagonist.

Proliferation assays. Cell proliferation was evaluated using the tetrazolium compound 3-(4, 5-dimethylthiazol-2-yl)-5(3-carboxymethoxyphenyl)2-(4-sulfophenyl)-2H-tetrazolium, inner salt (MTS), according to the manufacturer's instructions (CellTiter 96 Aqueous One-Solution Cell Proliferation Assay, Promega Corp., Madison, WI, USA). Cell numbers were quantified using a Coulter counter. The plate included blank wells ( 0 cells $/ 0.1 \mathrm{ml})$, control wells $\left(10^{4}\right.$ cells $\left./ 0.1 \mathrm{ml}\right)$, control wells with DMSO or acetonitrile, control wells treated with SP, control wells treated with the NK-1 receptor antagonist, and control wells treated with the most mitogenic exogenous at $\mathrm{SP} \mathrm{nM}$ concentration and the NK-1 receptor antagonist [50\% $\mu \mathrm{M}$ inhibition concentration $\left(\mathrm{IC}_{50}\right)$ of antagonist for their first doubling times]. For the proliferation assay, $20 \mu \mathrm{l}$ of the MTS reagent was added to each well 90 min before reading the samples on a multiscanner microplate reader (Tecan Spectra classic, Barcelona, Spain) at $492 \mathrm{~nm}$. Each experimental condition (blank wells, control wells, and control wells treated with the different concentrations of each antagonist and/or SP) was assayed in duplicate and all experiments were performed at least three times. The $\mathrm{IC}_{50}$ of the NK-1 receptor antagonists was calculated using the regression straight line function based on the least squares technique. 

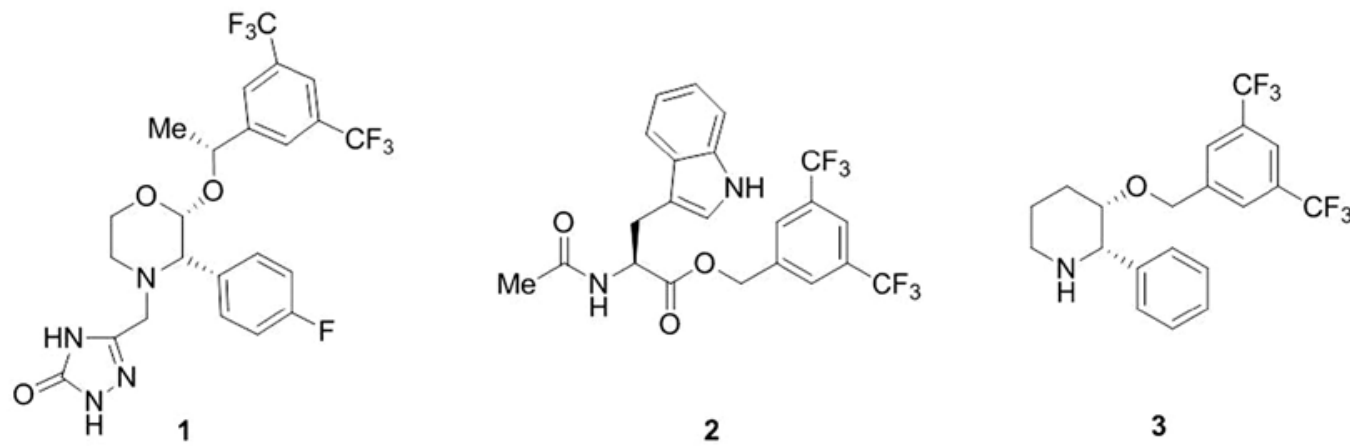

Figure 1. Aprepitant (1), L-732,138 (2) and L-733,060 (3) chemical structures.

Statistical analyses. Data are expressed as the means \pm SD. Statistical analysis was performed with SPPS statistical software for Microsoft Windows, release 14.0 (Professional Statistic, Chicago, IL, USA). The homogeneity of variance was tested using the Levene test. If the variances were homogeneous, the data were analyzed using the one-way ANOVA test with Bonferroni's correction for multiple comparisons. For data sets with non-homogeneous variances, the ANOVA test with T3 Dunnett post-hoc analysis was applied. The criterion for significance was $\mathrm{p}<0.05$ for all comparisons.

Western blot analyses. As previously reported (30), total protein was prepared from subconfluent MT-3, MCF-7, BT-474, MDA-MB-468, MCF-10A and MCF-12A human cell cultures. Protein concentrations were determined using the protein assay kit from Bio-Rad according to the manufacturer's instructions.

From each sample, $50 \mu \mathrm{g}$ of protein was separated by electrophoresis on 10\% SDS-polyacrylamide gels and electroblotted onto PVDF membranes. Blots were incubated in blocking solution [5\% non-fat milk in phosphate-buffered saline (PBS), 0.1\% Tween-20 (PBS-T)], followed by overnight incubation with antibodies against the KTMTESSSFYSNMLA conserved domain, corresponding to the C-terminus of the NK-1 receptor (product no. S8305, Sigma-Aldrich) $(1: 4,000$ dilution), against poly-(ADP)-ribose polymerase (PARP) (product no. 118352380001, Roche) (1:1,000 dilution), against cleaved caspase-3 (Asp175) (product no. 9664, Cell Signaling) (1:1,000 dilution), and against $\beta$-actin (product no. A2066, Sigma) (1:1,000 dilution) that was used as endogenous control to ensure the equal amount of protein loading. Membranes were then washed with PBS-T and incubated with a horseradish peroxidase-conjugated goat anti-rabbit IgG antibody for $2 \mathrm{~h}$ at room temperature (1:10,000 dilution). Antibody detection was performed with an enhanced chemiluminescence reaction (ECL Western blotting detection; Amersham Life Science, UK). Chemiluminescence on membranes was detected after ECL treatment (Amersham, Piscataway, NJ, USA) and image capture using a Fujifilm LAS3000 imaging system. Image Gauge software was used to perform the densitometric quantification of each protein.

Immunohistochemical staining for $N K-1$ receptors and $S P$. Twelve breast human carcinomas specimens were retrieved from the archives of the Department of Pathology of the Virgen del Rocío University Hospital, Sevilla, Spain, corresponding to infiltrating ductal breast carcinoma. Age at diagnosis ranged between 36 and 82 years. The experimental design, protocols, and procedures of this work were performed under the guidelines of the ethics and legal recommendations of Spanish and European law, as well as in accordance with the Declaration of Helsinki.

Paraffin-embedded breast human carcinoma tissues cut at $5 \mathrm{~mm}$ and dried overnight at $60^{\circ} \mathrm{C}$ were used. The sections were deparaffinized with xylene, hydrated through a series of solutions containing decreasing concentrations of ethanol and immersed in distilled water. After pressure-cooker antigen retrieval in citrate buffer, $\mathrm{pH} 6.0$, slides were allowed to cool at room temperature for $10 \mathrm{~min}$. Endogenous peroxidase activity was blocked with $3 \%$ hydrogen peroxide for $30 \mathrm{~min}$ at room temperature. After washing in $0.05 \mathrm{M}$ Tris, sections were incubated with $10 \%$ non-immune pig serum for $30 \mathrm{~min}$ at room temperature. Subsequently, they were incubated overnight at $4{ }^{\circ} \mathrm{C}$ with $1: 1,000$ diluted anti-NK-1 receptor antibody (Sigma-Aldrich) or 1:3,000 diluted anti-SP antibody (Sigma-Aldrich). Sections were then washed in $0.05 \mathrm{M}$ Tris at room temperature. Sections were incubated in the Envision + System-HRP (Dako) reagents for $30 \mathrm{~min}$ at room temperature. The slides were rinsed in $0.05 \mathrm{M}$ Tris, and the immunoreactivity was visualized using a 3, 3'-diaminobenzidine chromogen solution (DAB ${ }^{+}$, Dako). Cell nuclei were lightly counterstained with hematoxylin. Finally, as previously reported $(15,30,31)$, in order to determine the specificity of the immunostaining, human gliomas were used as a positive control, while as a negative control the primary antibody was omitted, being replaced by non-immune serum. In both cases, the results obtained confirmed the specificity of the anti-NK-1 receptor antibody used. Moreover, preabsorption of the primary antibodies with the corresponding synthetic peptides $(100 \mu \mathrm{g}$ per $\mathrm{ml}$ of diluted antiserum) were carried out. In all the cases, the results obtained confirmed the specificity of the anti-NK-1 receptor and anti-SP antibodies used. All slides were evaluated by two independent pathologists. In each slide, 10 representative high-power microscopic fields were evaluated using a 40x objective. The presence or absence of staining and the intensity of the immunoreactivity were noted, as well as the number of cells showing a brown staining and whether or not the staining was localized in the 
tumor cells and/or in the plasma membrane. Tumors were recorded as positive when they showed cellular and/or plasma membrane staining ranging from moderate to strong in $>10 \%$ of the tumor cells. By consensus among the pathologists, the intensity of the immunoreactivity was evaluated as 'acceptable' only if the tumor cells showed a clear brown staining localized in the cytoplasm, nucleus and/or plasma membrane of the tumor cells. The number of immunoreactive cells acceptable was quantified as follows: negative (0), if the immunoreactivity was observed in $<10 \%$ of the tumor cells; positive (+), if the immunoreactivity was found to be between 11 and $50 \%$ of the tumor cells and strongly positive $(++)$ when present in $>50 \%$ of the tumor cells.

DAPI staining. In order to determine whether the NK-1 receptor antagonists studied induced apoptosis, DAPI staining was performed. After treatment with NK-1 receptor antagonists for their approximate first doubling times or after the application of the knockdown method (see below), the cells were fixed in $4 \%$ paraformaldehyde. Following a second wash in PBS, cells were incubated in DAPI solution (Sigma-Aldrich) at a dilution of 1/1,000 $(1 \mu \mathrm{g} / \mathrm{ml})$ for $30 \mathrm{~min}$ in the dark. Cells were then observed through a fluorescence microscope (Zeiss, Oberkochen, Germany). Apoptotic cells were defined by chromatin condensation and nuclear fragmentation. We counted the number of apoptotic cells, repeating the counts on three different slides. Finally, on each slide, we counted the number of apoptotic cells located in five different sequential fields.

Polymerase chain reaction (PCR). From cultured cells (BT-474, MCF-7, MDA-MB-468, MT-3, MCF-10A and MCF-12A), total RNA isolation was achieved with the NucleoSpin RNA II kit (Macherey-Nagel), allowing the purification of $\sim 5 \times 10^{6}$ cultured cells. Final RNA was dissolved in RNase-free water. The purity and quality of the RNA purified were also checked. Reverse transcription with elimination of genomic DNA was performed according to the manufacturer's instructions (QuantiTect Reverse transcription Handbook, Qiagen). All reactions were carried out on ice in order to minimize the risk of RNA degradation. The cDNA obtained was kept at $-80^{\circ} \mathrm{C}$.

From the cDNA preparation, $4 \mu \mathrm{l}$ was used in PCR with specifics primers according to the modified method of Bigioni et al (11) based on the common sequence of the TAC1R human isoforms (NM 001058, NM 015727) TAC1R-forward (CTG CTG GTG ATT GGC TAT GC) and TAC1R-reverse (AGG AGG AAG AAG ATG TGG AAG G), which yielded a 186-bp fragment. The amplification of the specimen was performed in a final reaction volume of $20 \mu \mathrm{l}$, and was incubated at $95^{\circ} \mathrm{C}$ for $7 \mathrm{~min}$, subjected to 40 cycles of $95^{\circ} \mathrm{C}$ for $30 \mathrm{sec}, 62^{\circ} \mathrm{C}$ for $40 \mathrm{sec}$ and $72^{\circ} \mathrm{C} 30 \mathrm{sec}$, followed by a final extension cycle at $72^{\circ} \mathrm{C}$ for $7 \mathrm{~min}$. The amplification products were visualized by electrophoresis on $2 \%$ agarose gel stained with ethidium bromide.

Real-time quantitative RT-PCR. Real-time quantitative RT-PCR was performed as described previously (16). Reverse transcription with elimination of genomic DNA was performed according to the manufacturer's instructions (QuantiTect Reverse transcription Handbook, Qiagen). Real-time quantitative RT-PCR analysis was performed using a de Roche Light
Cycler with a fluorogenic detection system (SYBR green). The $\beta$-actin gene was chosen as the housekeeping gene for normalization. The sequences of primers for the human NK-1 receptor were based on the common sequence of the TAC1R human isoforms (NM 001058, NM 015727), TAC1R-foward (CTG CTG GTG ATT GGC TAT GC) and TAC1R-reverse (AGG AGG AAG AAG ATG TGG AAG G), which yielded a 186-bp fragment and for $\beta$-actin gene were used forward primer CGGCATCGTCACCAACTG, and the reverse primer CACGCAGCTCATTGTAGAAGGT, yielding a 70-bp fragment. All amplification reactions were performed in a final volume of $20 \mu \mathrm{l}$ containing $2 \mu \mathrm{l}$ of the Master Mix PCR and $2 \mu \mathrm{l}(1 \mu \mathrm{g})$ of cDNA. The primer concentrations were optimized as follows: $500 \mathrm{nM}$ for the NK-1 receptor forward primer and reverse primer; $300 \mathrm{nM}$ for $\beta$-actin forward primer and reverse primer. PCR for the NK-1 receptor included 40 cycles. In each cycle, the temperature reached $92^{\circ} \mathrm{C}$ for $10 \mathrm{sec} ; 62^{\circ} \mathrm{C}$ for $15 \mathrm{sec}$, and $72^{\circ} \mathrm{C}$ for $10 \mathrm{sec}$, while the conditions for PCR for the $\beta$-actin were $95^{\circ} \mathrm{C}$ for $5 \mathrm{sec} ; 58^{\circ} \mathrm{C}$ for $15 \mathrm{sec}$ and $72^{\circ} \mathrm{C}$ for $10 \mathrm{sec}$. Data were analyzed using the relative standardcurve method, as reported previously (16). Experiments were performed in duplicate for each data point. Each PCR run included five standard samples, two negative controls, and the experimental samples. Standard curves for both NK-1 receptor and $\beta$-actin were generated using cDNAs from MT-3, MCF-7, BT-474 and MDA-MB-468 BC and HEK-293, MCF-12A and MCF-10A non-tumor cell lines. For each experimental sample, the relative amounts (copy number) of NK-1 receptor mRNA and $\beta$-actin mRNA were respectively determined from the standard curve. The normalized amount of NK-1 receptor was determined by dividing the amount of NK-1 receptor mRNA by the amount of $\beta$-actin mRNA for each sample. For MT-3, MCF-7, BT-474 and MDA-MB-468 BC cell lines and the HEK-293 non-tumor cell line and MCF-12A and MCF-10A epithelial breast cell lines, NK-1 receptor mRNA and $\beta$-actin mRNA analysis was repeated four times in duplicate.

Small interfering RNA (siRNA) gene silencing method. We carried out this method according to the manufacturer's instructions (Invitrogen, Madrid, Spain) and according to a previous study $(16,23,32)$. This procedure was carried out three times. One day before transfection, $2 \times 10^{4}$ cells per well from the BT-474, MCF-7, MDA-MB-468 and MT-3 human $\mathrm{BC}$ cell lines were seeded in 6 -wells plates containing $2 \mathrm{ml}$ of normal growth medium. Total cell number was determined the day before the transfection. Cells were incubated at $37^{\circ} \mathrm{C}$ in a $\mathrm{CO}_{2}$ incubator for 17-20 $\mathrm{h}$ for normalization. Then, the normal growth medium was removed and an antibiotic-free growth medium (Opti-MEM; Gibco) was added and incubated for $1 \mathrm{~h}$. The latter medium was removed and then the transfection mixture was added, which contained the siRNA TAC1R (Tachykinin 1 gene) (Invitrogen) and the diluted transfection reagent medium (Hiperfect, Qiagen); the latter two were previously incubated for $30 \mathrm{~min}$. Following this, the final volume obtained was $200 \mu \mathrm{l}$. In the same way, this method was applied to siRNA-negative control solution. For each transfection, $200 \mathrm{ml}$ siRNA transfection reagent mixture was added to each well containing $800 \mathrm{ml}$ of the antibiotic-free growth medium. The final siRNA concentration used for each transfection was $20 \mathrm{nM}$. It was incubated for $4-5 \mathrm{~h}$ at $37^{\circ} \mathrm{C}$ in a $\mathrm{CO}_{2}$ incubator. 
A

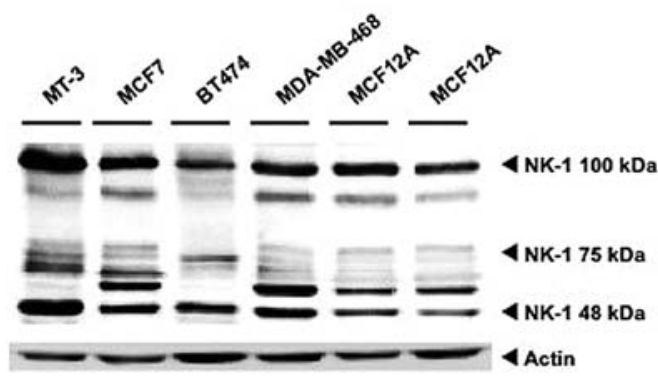

B

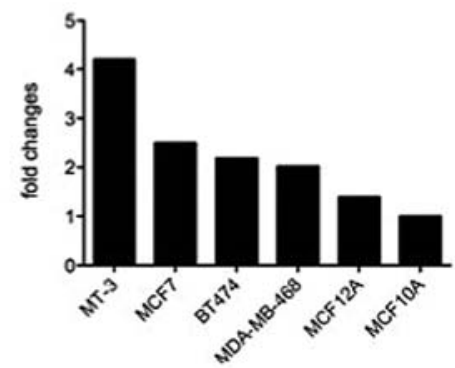

C
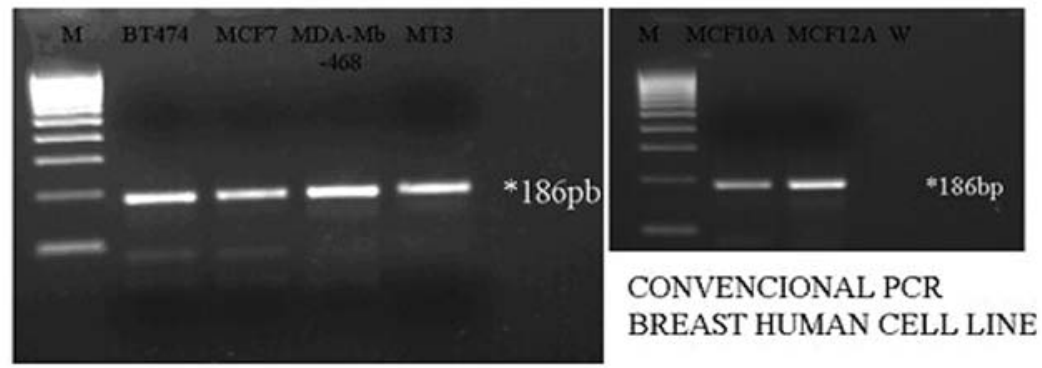

Figure 2. (A) Western blot analysis showing the expression of NK-1 in human breast cancer (BT-474, MCF-7, MDA-MB-468, MT-3) and normal breast epithelial (MCF-10A and MCF-12A) cell lines. The diffuse and multiband expression pattern observed corresponds with the different levels of glycosylation of the NK-1 receptor. (B) Quantification of the molecular isoform corresponding to the non-glycosilated 48-kDa band. (C) Agarose gel showing expression of TACIR cDNA in human BC and normal breast epithelial cell lines. Equal aliquots of each cDNA were amplified by PCR for 40 cycles (target genes) with specific primers.

Finally, $2 \mathrm{ml}$ of normal growth medium was added for an additional 72-h incubation.

\section{Results}

Breast cancer and breast epithelial cell lines express $N K-1$ receptors. We carried out western blot analyses in order to test the presence of the NK-1 receptor in the human MT-3, MCF-7, BT-474 and MDA-MB-468 BC cell lines and in the human MCF-10A and MCF-12A breast epithelial cell lines. Incubation of the membranes with the anti-NK-1 receptor antibody revealed the presence of different isoforms of the NK-1 receptor (Fig. 2A), corresponding to the different $\mathrm{N}$-glycosylation levels that this receptor undergoes after synthesis (33). The quantification for the band corresponding to $\sim 50 \mathrm{kDa}$ in each cell line is shown (Fig. 2B). No bands were detected when incubation was performed with the secondary antibody alone and in addition as a positive control (not shown), a protein extract from a glioma cell line was included (30).

From the PCR analyses, we also observed that the BT-474, MCF-7, MDA-MB-468, MT-3 and MCF-10A and MCF-12A human cell lines expressed mRNA for the tachykinin NK-1 receptor (Fig. 2C). NK-1 mRNA expression was detectable in these cell lines as a product of the expected size of $186 \mathrm{bp}$, corresponding to only one band because the primers used in our PCR were designed for both short and long isoforms.

Real-time quantitative RT-PCR was performed to analyze NK-1 receptor expression using $\beta$-actin as a control (Fig. 3). The mean NK- 1 receptor $/ \beta$-actin ratio was $45 \pm 1.2,35 \pm 3.1$, $23 \pm 1.08,63 \pm 1.27$ for BT- 474 , MCF-7, MDA-MB-468 and MT-3 human BC cell lines. However, the ratio was 1.6 \pm 3.9 for HEK-293 non-tumor cell line and 1.8 \pm 1.92 for MCF-12A and $2.1 \pm 1.96$ for MCF-10A epithelial breast cell lines (Table I). Thus, the NK-1 receptor mRNA level was $~ 20-60$-fold higher in BC cell lines than in the normal cell line (Table I).

Antitumor action of NK-1 receptor antagonists $(1,2$ and $(2 S$, 3S) 3-([3, 5-Bis (trifluoromethyl)phenyl]methoxy)-2-phenylpiperidine $(L-733,060))$. Growth inhibition of the BT-474, MCF-7, MDA-MB-468 and MT-3 human BC cell lines by different NK-1 receptor antagonists was observed after the addition of increasing concentrations of these antagonists (Fig. 4). 
A
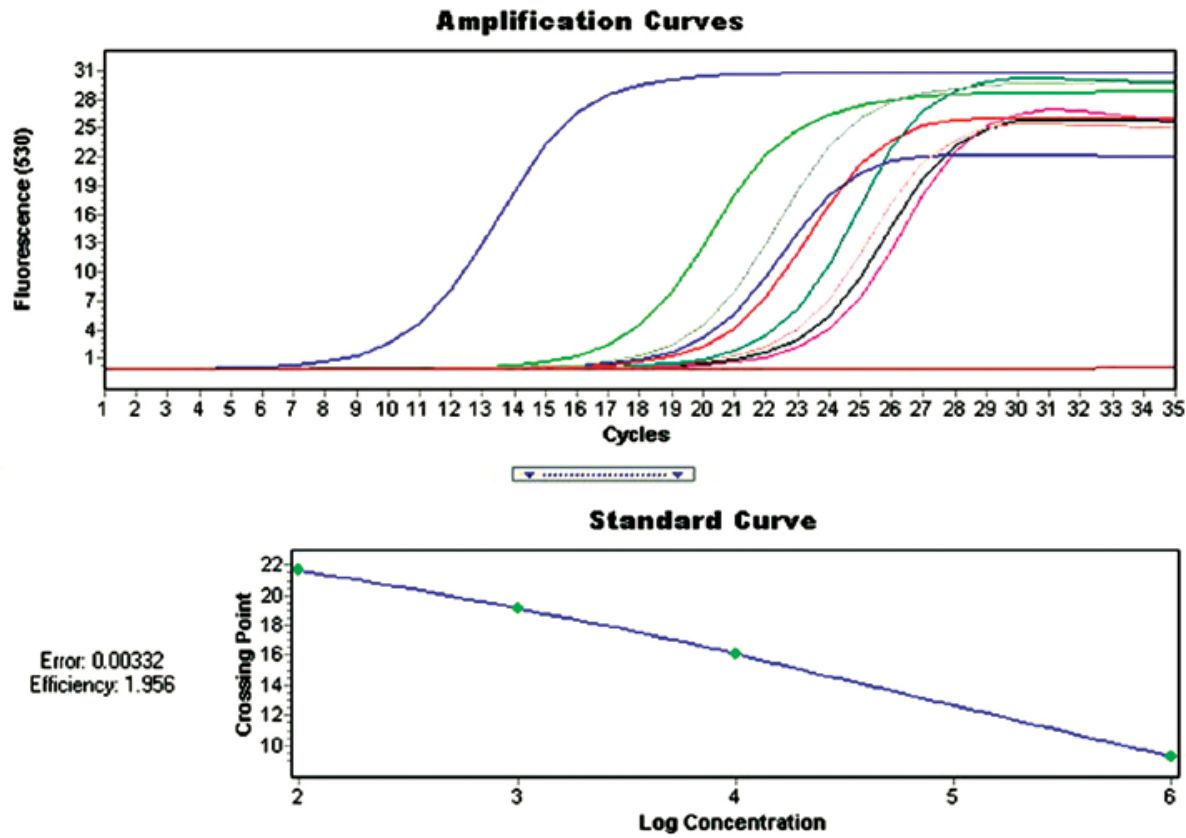

B
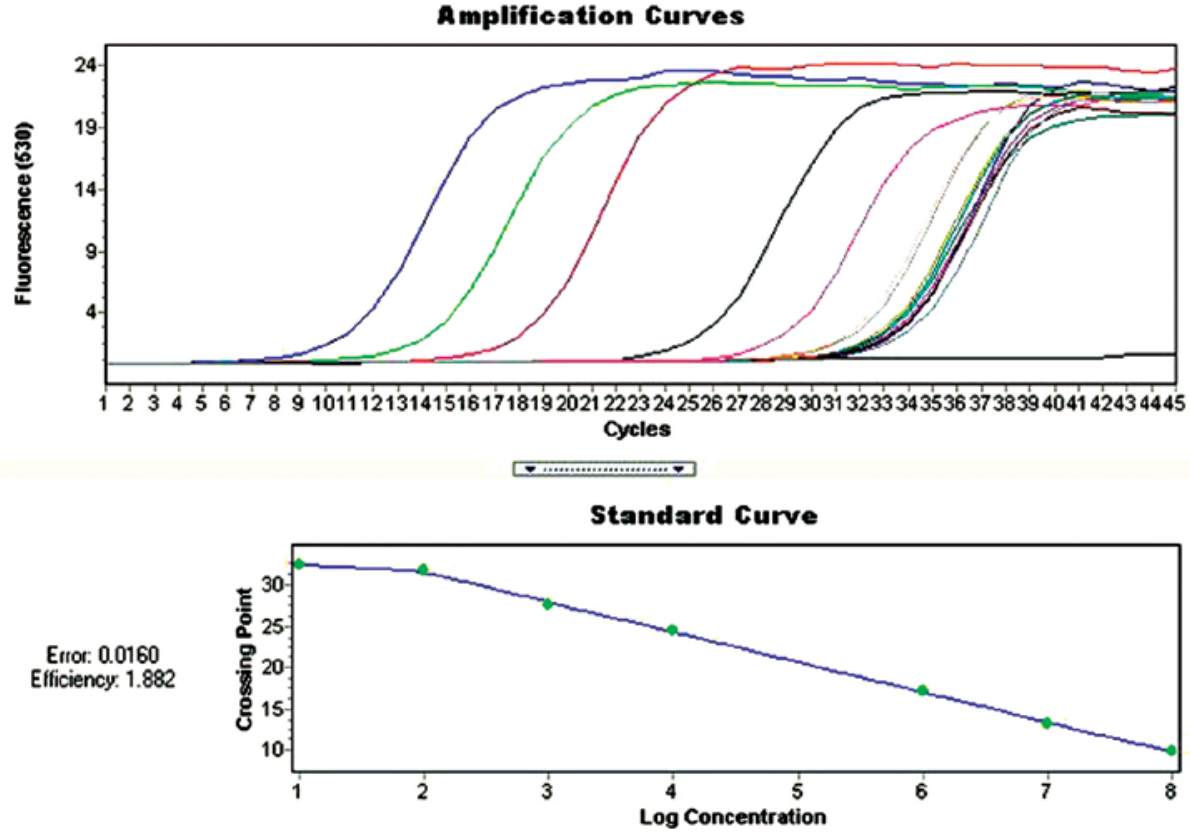

Figure 3. Amplification plot obtained by real-time quantitative RT-PCR for NK-1 receptor cDNA in BC cell lines (A) and in a non-tumor cell line and epithelial breast cell lines (B). Curves represent the fluorescence of SYBR green for amplification of the TAC1R fragment in standard and experimental samples. The negative control is also shown.

Table I. Real-time quantitative RT-PCR in BC and normal cell lines.

\section{Ratio $T A C / \mathrm{R} / \beta$-actin}

\begin{tabular}{ll} 
BT-474 & 45 \\
MCF-7 & 35 \\
MDA-MB-468 & 23 \\
MT-3 & 63 \\
HEK-293 & 1.6 \\
MCF-12A & 1.8 \\
MCF-10A & 2.1 \\
\hline
\end{tabular}

Moreover, treatment of both cell lines with the three antagonists resulted in a concentration-dependent cytotoxicity. From Fig. 4, the $\mathrm{IC}_{50}(50 \%$ inhibitory concentration) at the first doubling times can be calculated. Thus, the concentrations required for a $50 \%$ reduction in optical density $\left(\mathrm{IC}_{50}\right)$ observed in the controls treated with L-733,060 (L-733,060) (Fig. 1) were $10.6 \mu \mathrm{M}$ for BT-474, $16.4 \mu \mathrm{M}$ for MCF-7, $13.8 \mu \mathrm{M}$ for MDA-MB-468 and $8.4 \mu \mathrm{M}$ for MT-3; with L-732,138 they were $25.4 \mu \mathrm{M}$ for BT-474, $28.8 \mu \mathrm{M}$ for MCF-7, 27.1 $\mu \mathrm{M}$ for MDA-MB-468 and $27.3 \mu \mathrm{M}$ for MT-3, and with aprepitant they were $31.4 \mu \mathrm{M}$ for BT-474, 35.6 $\mu \mathrm{M}$ for MCF-7, 29.5 $\mu \mathrm{M}$ for MDA-MB-468 and $40.8 \mu \mathrm{M}$ for MT-3 (Table II). Maximum inhibition was 

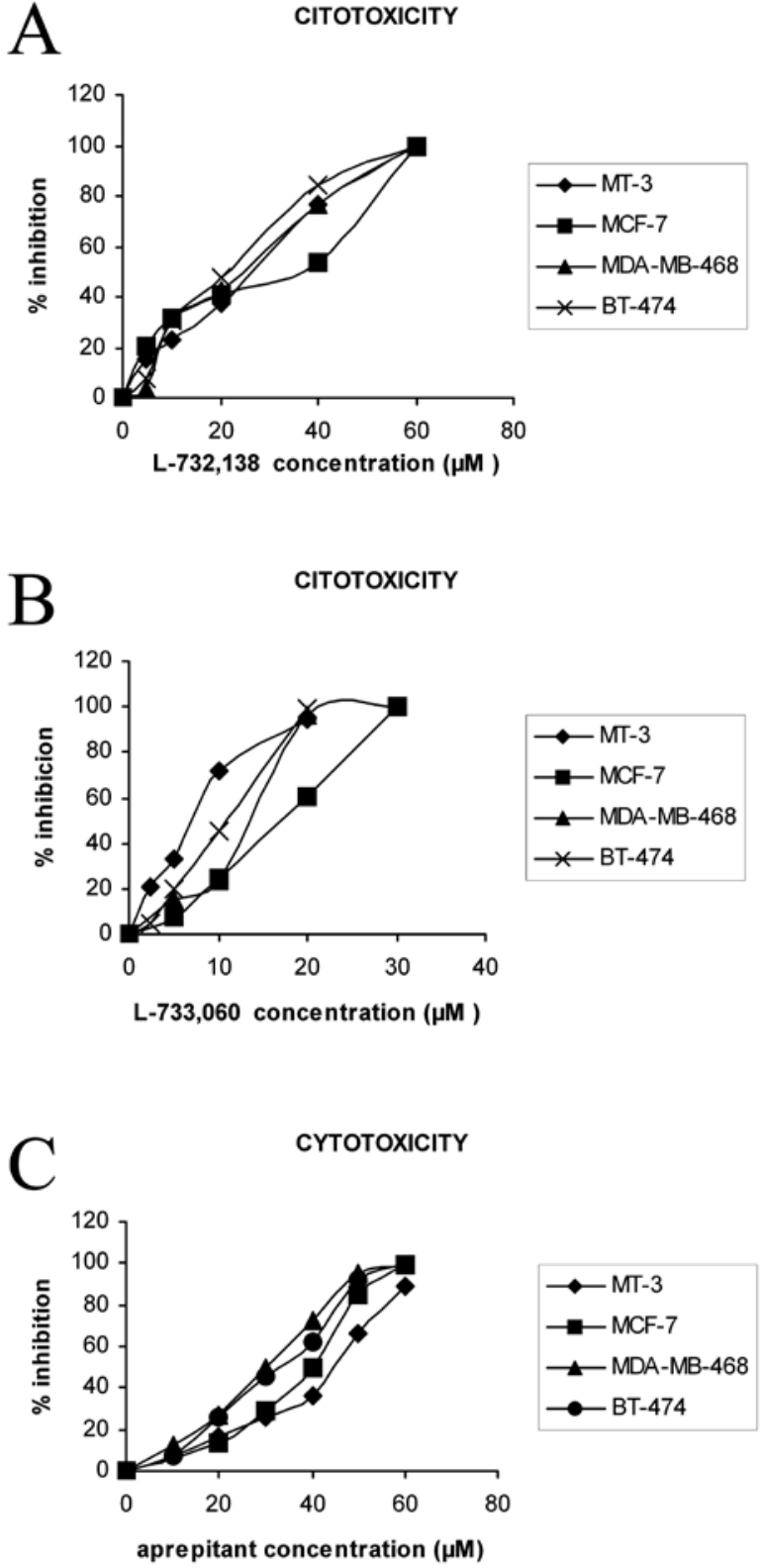

Figure 4. Percentage of growth inhibition of human BT-474, MCF-7, MDAMB-468 and MT-3 BC cells at first doubling time, respectively, in in vitro cultures following the addition of increasing concentrations $(2.5-30 \mu \mathrm{M})$ of L-733,060, $(5-60 \mu \mathrm{M})$ of L-732,138 or $(10-60 \mu \mathrm{M})$ of aprepitant. The percentage of inhibition for the first doubling time of incubation is plotted on a linear graph. Level of significance: " $\mathrm{p} \leq 0.05$. Values are means $\pm \mathrm{SD}$ (bars). The regression line is not indicated, neither the equation used to obtain the $\mathrm{IC}_{50}$. observed when the drug was present at a concentration of $20.4 \mu \mathrm{M}$ of L-733,060, $58 \mu \mathrm{M}$ of L-732,138 or $59.1 \mu \mathrm{M}$ of aprepitant (BT-474); $31 \mu \mathrm{M}$ of L-733,060, $64.1 \mu \mathrm{M}$ of L-732,138 or $64 \mu \mathrm{M}$ of aprepitant (MCF-7); $27.1 \mu \mathrm{M}$ of L-733,060, $56.8 \mu \mathrm{M}$ of L-732,138 or $57 \mu \mathrm{M}$ of aprepitant (MDA-MB-468), and $18.8 \mu \mathrm{M}$ of $733,060,57.7 \mu \mathrm{M}$ of $\mathrm{L}-732,138$ or $75.3 \mu \mathrm{M}$ of aprepitant (MT-3) during the culture periods. At the first doubling time, a strong decrease in the number of the four cell lines was found at intermediate concentrations and with the maximum concentration no remaining living cells were observed. A lower inhibition of growth of the four cell lines was observed in the presence of low doses of each antagonist. In Table II, the $\mathrm{IC}_{50}$ and $\mathrm{IC}_{100}$ values for $\mathrm{BC}$ cells are indicated.

After administration of aprepitant the $\mathrm{IC}_{50}$ for MCF-10A and MCF-12A human breast epithelial cell lines was, in both cases, $>90 \mu \mathrm{M}$ (data not shown in Table II).

NK-1 receptor antagonists block $S P$-induced mitogen stimulation. Growth of the BT-474, MCF-7, MDA-MB-468 and MT-3 human BC cell lines was observed after the addition of $\mathrm{SP}$, and nanomolar concentrations of SP induced cell proliferation as compared to the controls (Fig. 5 and Table III). SP stimulation was evident at $5 \mathrm{nM}$ and the maximum level was reached at $10 \mathrm{nM}$ for BT-474, MCF-7 and MT-3 and $5 \mathrm{nM}$ for MDA-MB-468 (Fig. 5). This indicates that the activation of SP receptors leads to mitogenesis in the BT-474, MCF-7, MDA-MB-468 and MT-3 human BC cell lines. Thus, the percentage of cell proliferation increased from 7.5 to $17.3 \%$, depending on the dose of SP administered (Table III). Treatment with L-733,060 $(5 \mu \mathrm{M}), \mathrm{L}-732,138(10 \mu \mathrm{M})$ or aprepitant $(30 \mu \mathrm{M})$ partially inhibited the growth of cell lines (Fig. 5). In order to examine whether NK-1 receptor antagonists inhibited cell proliferation via an interaction with the NK-1 receptor, we used the specific NK-1 receptor agonist SP in competition experiments (Table III). Thus, the cellular concentration at $5 \mu \mathrm{M}$ of L-733,060, $10 \mu \mathrm{M}$ of L-732,138 or $30 \mu \mathrm{M}$ of aprepitant and 5-10 $\mathrm{nM}$ of SP was higher than that observed with NK-1 receptor antagonist alone (Fig. 5). These results indicate that L-733,060, L-732,138 and aprepitant block SP mitogen stimulation, since NK-1 receptor antagonist-induced growth inhibition was partially reversed by the administration of a nanomolar dose of exogenous SP. This indicates the specificity of tachykinin NK-1 receptor activation in the growth of the human BC cell lines, since an increase in the cellular concentration was observed,

Table II. Half inhibition $\left(\mathrm{IC}_{50}\right)$ and maximum inhibition $\left(\mathrm{IC}_{100}\right)$ experiments in $\mathrm{BC}$ cell lines following the administration of NK-1 receptor antagonists.

\begin{tabular}{lcccccccc}
\hline & \multicolumn{2}{c}{$\mathrm{L}-733,060$} & & \multicolumn{2}{c}{$\mathrm{L}-732,138$} & & \multicolumn{2}{c}{ Aprepitant } \\
\cline { 2 - 3 } & $\mathrm{IC}_{50}(\mu \mathrm{M})$ & $\mathrm{IC}_{100}(\mu \mathrm{M})$ & & $\mathrm{IC}_{50}(\mu \mathrm{M})$ & $\mathrm{IC}_{100}(\mu \mathrm{M})$ & & $\mathrm{IC}_{50}(\mu \mathrm{M})$ & $\mathrm{IC}_{100}(\mu \mathrm{M})$ \\
\hline BT-474 & 10.6 & 20.4 & & 25.4 & 58 & & 31.4 & 59.1 \\
MCF-7 & 16.4 & 31 & & 28.8 & 64.1 & & 35.6 & 64 \\
MDA-MB-468 & 13.8 & 27.1 & & 27.1 & 56.8 & & 29.5 & 57 \\
MT-3 & 8.4 & 18.8 & & 27.3 & 57.7 & & 40.8 & 75.3 \\
HEK-293 & 25 & 75 & & 60 & 114 & & 86.3 & 187.4 \\
\hline
\end{tabular}



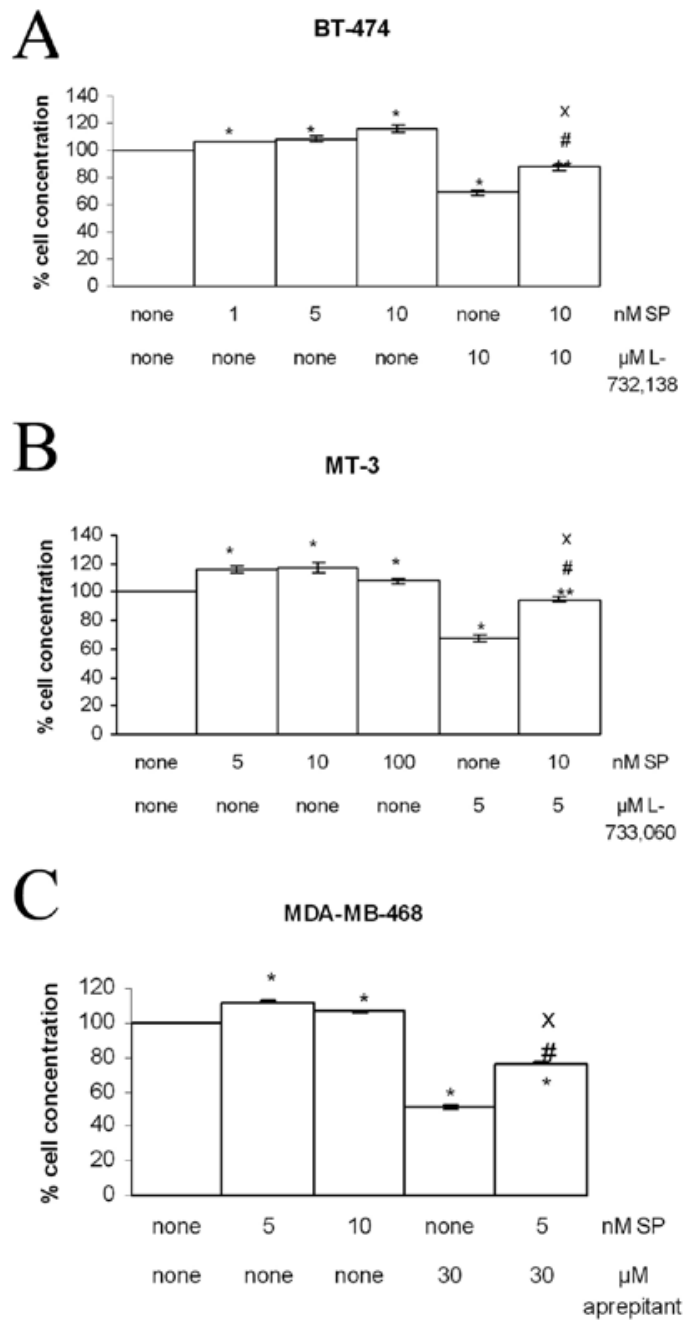

Figure 5. Induction of cell proliferation of human BT-474, MDA-MB-468 and MT-3 BC cell lines by SP at several nanomolar concentrations $(1,5,10$ and $100 \mathrm{nM}$ ). NK-1 receptor antagonists L-733,060, L-732,138 or aprepitant were added $(5,10$ and $30 \mu \mathrm{M}$ respectively) in the presence $(5$ or $10 \mathrm{nM})$ or absence (none) of SP for their first doubling time. In all cases, each NK-1 receptor antagonist inhibited human $\mathrm{BC}$ cell proliferation. Using the ANOVA test, a significant difference between each group and the control group (none-none) was found. Level of significance: ${ }^{*} \mathrm{p} \leq 0.01{ }^{* *} \mathrm{p} \leq 0.05$. "Value of significance of $\mathrm{IC}_{50}$ - most mitogenic SP concentration vs. $\mathrm{IC}_{50}$ - none $\mathrm{p}<0.05 ;{ }^{\mathrm{x}} \mathrm{IC}_{50}$ most mitogenic SP concentration vs. none-most mitogenic SP concentration, $\mathrm{p} \leq 0.01$. Vertical bars indicate SD. respectively, in BT-474, MCF-7, MDA-MB-468 and MT-3 human $\mathrm{BC}$ cell lines with respect to the values found when the antagonist was administered alone (Fig. 5). There were no significant differences between the control and the controlDMSO/acetonitrile (data not shown).

Apoptosis. To investigate the activation of apoptotic mechanisms, we carried out DAPI staining to assess for nuclear morphology and percentage of death cells. After administration of the NK-1 receptor antagonists many apoptotic cells were found in the BT-474, MCF-7, MDA-MB-468 and MT3 human $\mathrm{BC}$ cell lines (Fig. 6A-C). The percentage of apoptosis after treatment was estimated by counting the number of cells with aberrant chromatin condensation in DAPI-stained cultures. We observed an $86 \pm 2.0,23 \pm 3.1,85 \pm 1.1$ and $55 \pm 1.02 \%$ SD of apoptotic cells, respectively, in BT-474, MCF-7, MDA-MB468 and MT-3 human BC cell lines after administration of $\mathrm{IC}_{100} \mathrm{~L}-733,060$; and $50 \pm 2,2,34 \pm 1.15,23 \pm 1,7$ and $21 \pm 2.4 \%$ SD of apoptotic cells in the BT-474, MCF-7, MDA-MB-468 and MT-3 human BC cell lines respectively, after administration of $\mathrm{IC}_{100} \mathrm{~L}-732,138$. Furthermore, we observed $21 \pm 2.2,41 \pm 1.4$, $54.3 \pm 3.1$ and $34.3 \pm 2.34 \%$ SD of apoptotic cells in the BT-474, MCF-7, MDA-MB-468 and MT-3 human BC cell lines respectively after administration of $\mathrm{IC}_{100}$ aprepitant (Fig. 6D).

To further investigate whether aprepitant was able to induce cell death by activating apoptotic mechanisms, we determined the cleavage of PARP and the presence of cleaved caspase-3 by western blot analysis. We observed that the treatment with aprepitant induced an increase in the cleaved forms of PARP (88 kDa) and an increase in the cleaved caspase-3 form (18 kDa) (Fig. 6E and F), indicative of the activation of apoptosis.

Knockdown gene silencing method (siRNA). The knockdown method was carried out in BC cell lines. Thus, after $72 \mathrm{~h}$ we, respectively, found $1.26 \times 10^{6}, 1.04 \times 10^{6}, 8 \times 10^{5}, 9.6 \times 10^{5}$ siRNA-negative control BT-474, MCF-7, MDA-MB-468 and MT-3 BC cells and $5.8 \times 10^{5}, 3.2 \times 10^{5}, 4.4 \times 10^{5}, 4.4 \times 10^{5}$ siRNA TAC1R BT-474, MCF-7, MDA-MB-468 and MT-3 BC cells (Fig. 7). Moreover, after the administration of siRNA TAC1R to cultured cell lines, many apoptotic cells were found in all

Table III. BC cell proliferation by SP and SP/NK-1 receptor antagonist competition experiments.

\begin{tabular}{lcccc}
\hline & BT-474 & MCF-7 & MDA-MB-468 & MT-3 \\
\hline $\begin{array}{l}\text { Most mitogenic dose } \\
\text { of SP (nM) } \\
\% \text { proliferation }\end{array}$ & 10 & 10 & 5 & 10 \\
\hline & 115.7 & 107.5 & 112.1 & \\
\hline $\begin{array}{l}\text { SP/L-733,060 } \\
\text { \% proliferation }\end{array}$ & BT-474 & MCF-7 & MDA-MB-468 & \\
SP/L-732,138 & 94.77 & 87.3 & 87.6 & 94.3 \\
$\%$ proliferation & $(10 \mathrm{nM} / 5 \mu \mathrm{M})$ & $(10 \mathrm{nM} / 10 \mu \mathrm{M})$ & $(5 \mathrm{nM} / 10 \mu \mathrm{M})$ & $(10 \mathrm{nM} / 10 \mu \mathrm{M})$ \\
SP/aprepitant & 87.5 & 95.1 & 86.3 & 93.6 \\
\hline
\end{tabular}


A
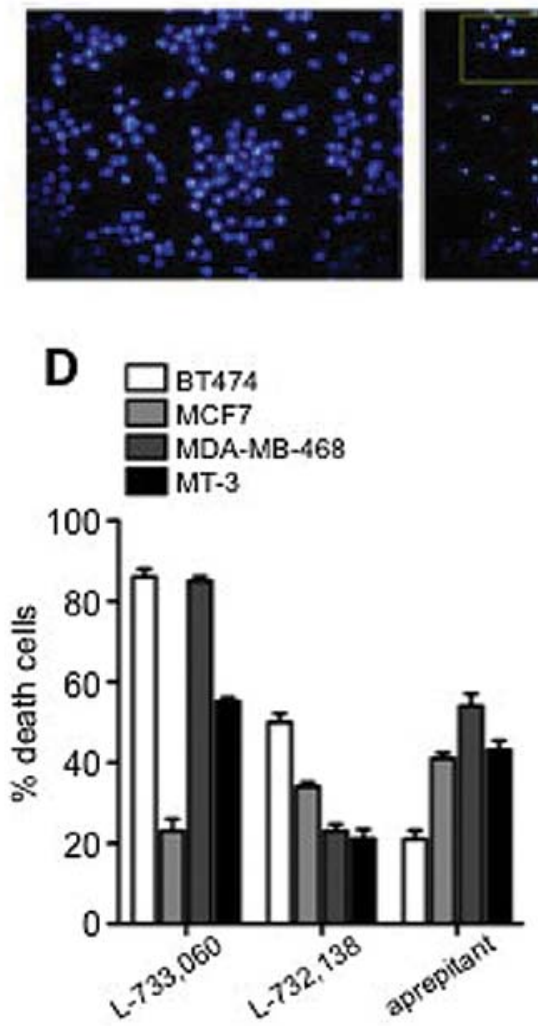

B

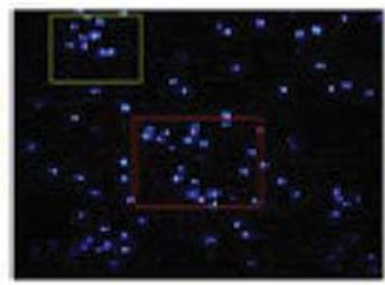

C

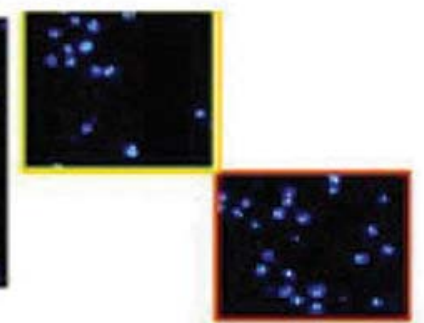

E
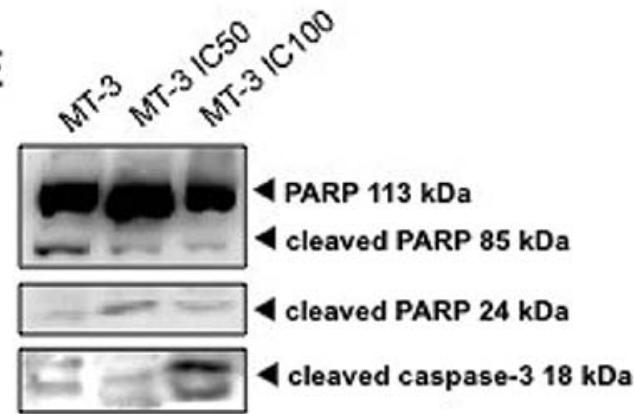

$\longrightarrow$ actin

F

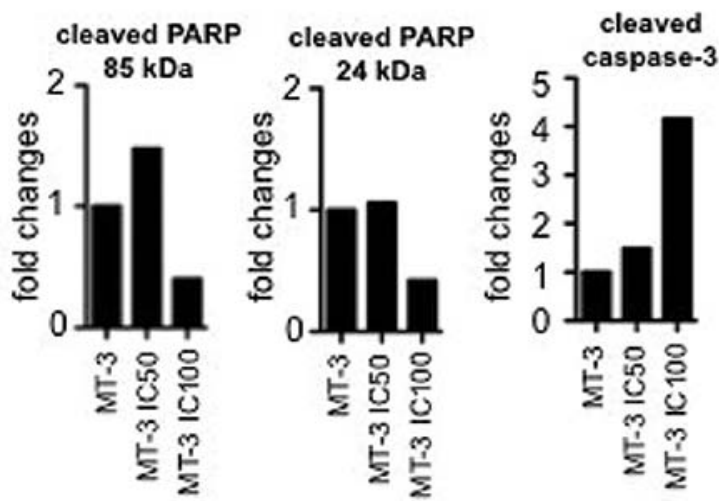

Figure 6. (A) Human MT-3 BC cell line. Representative DAPI images of non-treated culture cells (x20). (B) Culture cells treated with IC ${ }_{100} 3$ (x20) showed nuclei condensation and apoptotic features. (C) Higher-power magnifications of the regions delimited in the rectangles shown in (B) (x40). (D) Bar graph showing the percentage of cells with apoptotic nuclei after the treatment with L-733,060, L-732,138 and aprepitant. (E) Western blot analysis showing the effects of aprepitant on the cleavage of PARP and on the activation of caspase-3. Actin was used as endogenous control. (F) Densitometric quantification of the western blots shown in (E).

Table IV. Means of apoptotic cells after the application of the knockdown gene-silencing method.

\begin{tabular}{lcccc}
\hline & $\begin{array}{c}\text { \% apoptosis } \\
\text { siRNA-negative }\end{array}$ & SD & $\begin{array}{c}\text { \% apoptosis } \\
\text { siRNA TAC1R }\end{array}$ & SD \\
\hline BT-474 & 3 & 1.3 & 36 & 2.9 \\
MCF-7 & 8 & 0.6 & 37 & 1.2 \\
MDA-MB-468 & 7.6 & 1 & 31 & 1.2 \\
MT-3 & 11 & 1.3 & 52.4 & 1.3
\end{tabular}

the wells studied (Table IV). In the DAPI-stained cultures the mean was $39.1 \pm 1.6 \%$ (SD) of apoptotic cells. However, in the siRNA-negative control cells, we observed means of $7.4 \pm 1.05 \%$
(SD) (Table IV). All these data show that NK-1 receptors play an important role in the viability of such tumor cells.

$N K-1$ receptor-and $S P$-immunoreactivity in $B C$. Using an immunhistochemical technique, twelve infiltrating ductal breast carcinomas were examined for the presence of NK-1 receptors and SP. The expression of NK-1 receptors and SP was observed in all the breast carcinoma samples studied (12/12). The immunoreactivity for the NK-1 receptor was mainly found in the cytoplasm (Fig. 8C) and occasionally in the nuclei of tumor cells (Table V), whereas SP-immunoreactivity was predominantly located in the nucleus showing a strong staining (Fig. 8D). Moreover, the immunoreactivity for NK-1 receptors was observed in the peritumor area, in macrophages and in plasma cells. Immunoreactivity for SP was also observed in the nucleus of smooth muscle cells and in the endothelial 

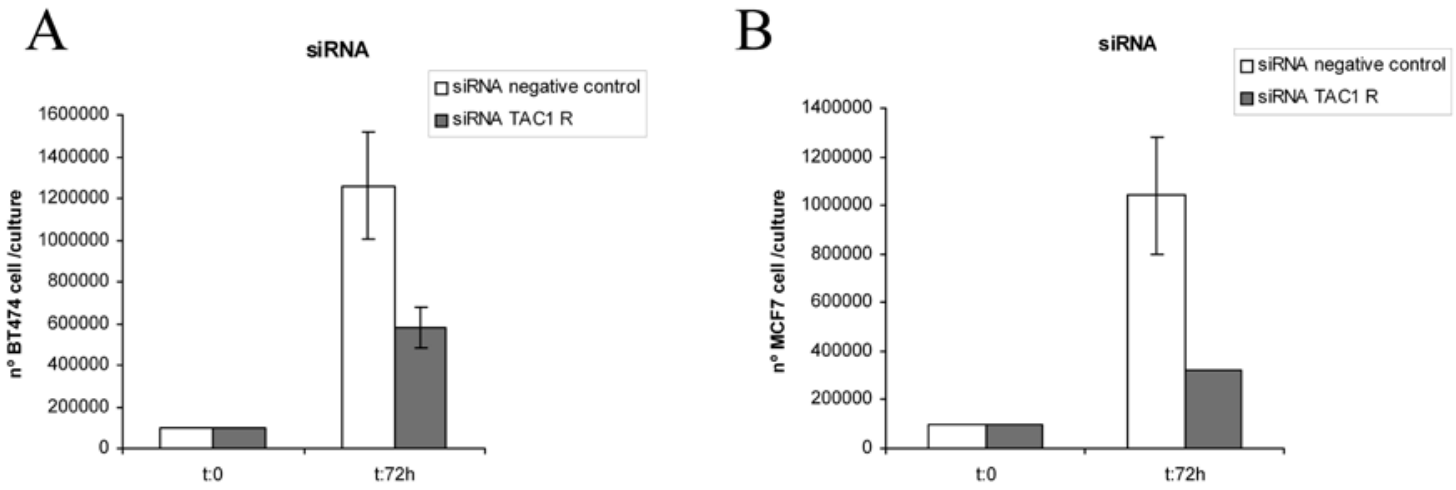

$\mathrm{C}$

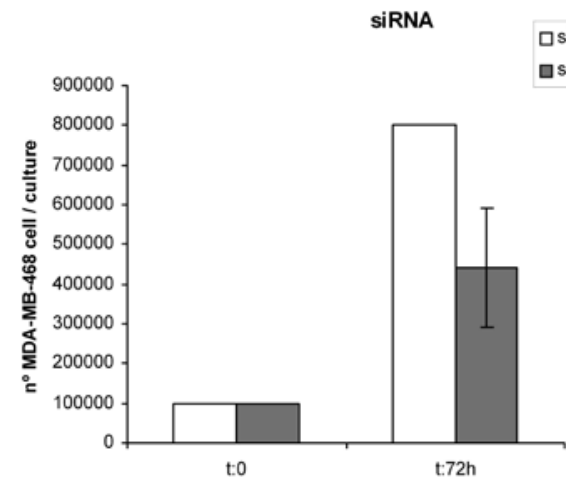

$\mathrm{D}$

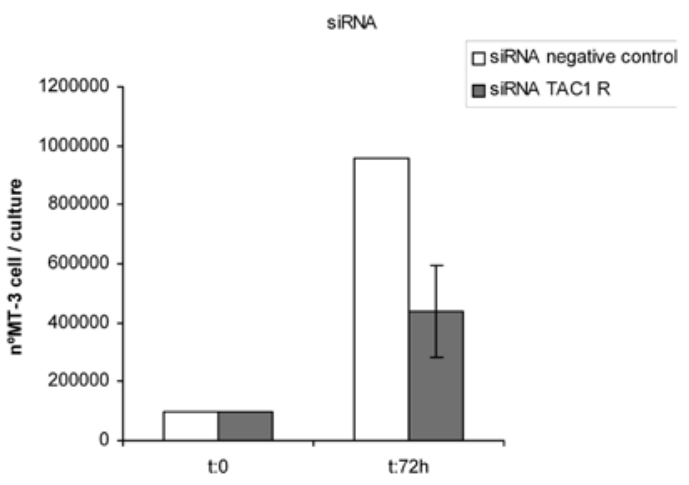

Figure 7. Viability of BT-474 (A), MCF-7 (B), MDA-MB-468 (C) and MT-3 (D) BC cells. The number of siRNA-negative control cells is compared with the number of siRNA TAC1R cells. At time 0,100,000 human BC cells were seeded. In all the cases, at $72 \mathrm{~h}$, the decrease in the number of siRNA TAC1R cells was significant in comparison with the number of siRNA-negative control cells.
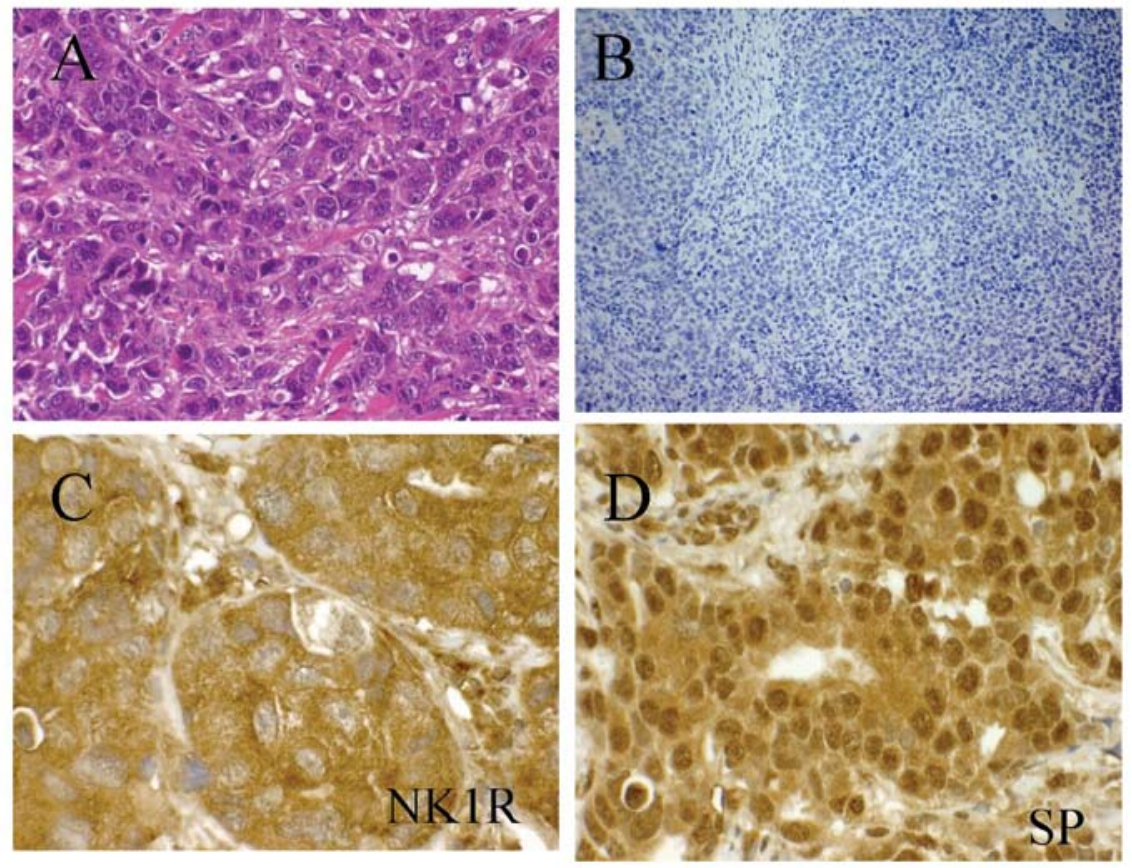

Figure 8. (A) Hematoxylin and eosin in breast tumor tissue (x20). (B) Negative control of breast tumor tissue (x10). (C) NK-1 receptor expression in the cytoplasm of BC cells. (D) SP expression in the nucleus of BC cells.

cells of the small- and medium-calibre blood vessels, in the nucleus of macrophages located in the peritumor area and in the nucleus and the cytoplasm of plasma cells. The clinical data of patients included in this study, together with the results of the evaluation of the expression of the NK-1 receptors and $\mathrm{SP}$ in tumor cells are shown in Table V. 
Table V. Inmunolocalization of NK-1 receptors and SP in BC samples.

\begin{tabular}{|c|c|c|c|c|c|c|c|c|c|c|c|c|c|c|}
\hline \multirow{4}{*}{$\frac{\text { Cases }}{1}$} & \multicolumn{6}{|c|}{ NK-1 receptor } & \multicolumn{6}{|c|}{ SP } & \multirow{2}{*}{\multicolumn{2}{|c|}{ Observations (tumor stage) }} \\
\hline & \multicolumn{3}{|c|}{ Nucleus } & \multicolumn{3}{|c|}{ Cytoplasm } & \multicolumn{3}{|c|}{ Nucleus } & \multicolumn{3}{|c|}{ Cytoplasm } & & \\
\hline & 1 & 2 & 3 & 1 & 2 & 3 & 1 & 2 & 3 & 1 & 2 & 3 & I & Grade IIB tumor in peritumor area, \\
\hline & $20^{\mathrm{a}}$ & - & - & - & $40^{\mathrm{b}}$ & 50 & - & 40 & 40 & 60 & 20 & - & $\%$ & and III in situ, lymph node metastases \\
\hline 2 & 1 & 2 & 3 & 1 & 2 & 3 & 1 & 2 & 3 & 1 & 2 & 3 & I & High-grade tumor metastases in the \\
\hline & $30^{\mathrm{a}}$ & - & - & - & 40 & 55 & 10 & 50 & 30 & 50 & 20 & - & $\%$ & majority of lymph nodes \\
\hline 3 & 1 & 2 & 3 & 1 & 2 & 3 & 1 & 2 & 3 & 1 & 2 & 3 & I & Grade IIB tumor, lymph node metastasis \\
\hline & 10 & - & - & - & 70 & 10 & 30 & 30 & 5 & 70 & 10 & - & $\%$ & without invading adipose tissue \\
\hline 4 & 1 & 2 & 3 & 1 & 2 & 3 & 1 & 2 & 3 & 1 & 2 & 3 & I & Grade III tumor, without metastases \\
\hline & - & - & - & - & 70 & 10 & 30 & 40 & & 50 & 20 & - & $\%$ & \\
\hline 5 & 1 & 2 & 3 & 1 & 2 & 3 & 1 & 2 & 3 & 1 & 2 & 3 & I & High-grade tumor, undifferentiated cells, \\
\hline & $10^{\mathrm{a}}$ & - & - & 20 & 40 & 10 & 20 & 30 & 20 & 60 & 20 & - & $\%$ & metastasis (6 months pregnant) \\
\hline 6 & 1 & 2 & 3 & 1 & 2 & 3 & 1 & 2 & 3 & 1 & 2 & 3 & I & Infiltrating ductal carcinoma recurrence \\
\hline & - & - & - & 10 & 40 & 20 & 1 & 1 & - & 20 & 10 & - & $\%$ & recurrence \\
\hline 7 & 1 & 2 & 3 & 1 & 2 & 3 & 1 & 2 & 3 & 1 & 2 & 3 & I & Grade I tumor, absence of metastasis \\
\hline & 20 & 10 & - & 20 & 50 & 10 & 30 & - & 10 & - & - & - & $\%$ & \\
\hline 8 & 1 & 2 & 3 & 1 & 2 & 3 & 1 & 2 & 3 & 1 & 2 & 3 & I & Grade III tumor, plus tumor tissue biopsy \\
\hline & 30 & - & - & 20 & 60 & 10 & 10 & 30 & 10 & 20 & 20 & - & $\%$ & \\
\hline 9 & 1 & 2 & 3 & 1 & 2 & 3 & 1 & 2 & 3 & 1 & 2 & 3 & I & Grade II tumor, rare foci of metastasis \\
\hline & $30^{\mathrm{a}}$ & 10 & - & 40 & 40 & $10^{\mathrm{b}}$ & 30 & 20 & - & - & 20 & 20 & $\%$ & \\
\hline 10 & 1 & 2 & 3 & 1 & 2 & 3 & 1 & 2 & 3 & 1 & 2 & 3 & I & Grade III tumor, node metastases \\
\hline & $20^{\mathrm{a}}$ & 10 & - & - & 40 & 40 & - & 30 & 10 & 20 & 5 & - & $\%$ & \\
\hline 11 & 1 & 2 & 3 & 1 & 2 & 3 & 1 & 2 & 3 & 1 & 2 & 3 & I & Grade IIA tumor, appearance of two \\
\hline & - & - & - & 10 & 10 & - & - & 20 & 10 & 20 & 10 & - & $\%$ & $\begin{array}{l}\text { separate tumors of } 2 \mathrm{~cm} \text {, no lymph } \\
\text { node metastases }\end{array}$ \\
\hline 12 & 1 & 2 & 3 & 1 & 2 & 3 & 1 & 2 & 3 & 1 & 2 & 3 & I & Grade I tumor, sentinel node metastases \\
\hline & - & - & - & 40 & - & - & - & 50 & 10 & 30 & - & - & $\%$ & \\
\hline
\end{tabular}

${ }^{\mathrm{a}}$ Granular. ${ }^{\mathrm{b}}$ Strengthening nuclear membrane. \%, percentage of expression. I, staining intensity.

\section{Discussion}

General considerations. This study confirms and complements several aspects previously published about the involvement of the SP/NK-1 receptor system in BC (e.g., the presence of NK-1 receptors, the fact that SP stimulates the proliferation of MDA-MB-231 cells, and the overexpression of the NK-1 receptor) $(9-11,24)$ and also reports the following in $\mathrm{BC}$ for the first time: i) the presence of $\mathrm{NK}-1$ receptors in the nuclei of BC cells; ii) mRNA expression for the NK-1 receptor and the overexpression of the NK-1 receptor in MT-3 human BC line; iii) the presence of SP in the nuclei of $\mathrm{BC}$ cells; iv) the involvement of the NK-1 receptor in the viability of BC cells after using a knockdown method; v) the mitogenic action of SP on MT-3 human BC line; vi) the total inhibition of BC cell growth after treatment with NK-1 receptor antagonists (aprepitant and L-732,138), this action being due to the apoptosis of $\mathrm{BC}$ cells; and vii) that the antitumor action exerted by the two antagonists against $\mathrm{BC}$ cells occurs through the NK-1 receptor concentration-dependently.

$N K-1$ receptor and $B C$. We report the presence of NK-1 receptors in $\mathrm{BC}$ samples and the presence of NK-1 receptors with different molecular weights in the $\mathrm{BC}$ cell lines corresponding to the different $\mathrm{N}$-glycosylation process that the receptor undergoes after synthesis (33). Moreover, we demonstrate that $\mathrm{NK}-1$ receptors are involved in the viability of $\mathrm{BC}$ cell lines, that these cell lines express mRNA for the NK-1 receptor, that $T A C 1 R$ cDNA is present in the $\mathrm{BC}$ cell lines studied and that the NK-1 receptor is overexpressed in these cell lines.

Our data are partially in agreement with previous studies in which the presence of NK-1 receptors has been reported by immunocytochemistry in a BC cell line (T47D) and in BC samples (10). The authors demonstrated the presence of NK-1 receptors in the plasma membrane and/or the cytoplasm of cancer cells. However, we observed NK-1 receptor-immunore- 
activity in the cytoplasm and in the nucleus of BC cells, but not in the plasma membrane. To date, the functional significance of the presence of NK-1 receptors in the nucleus of BC cells is unknown. It should be noted that we used the same antiNK-1 receptor antibody and methodology as that employed in previous studies $(15,23,31,34)$ in which the presence of NK-1 receptors in the nuclei of tumors cells was not observed. It should be also noted that we carried out several controls to check the specificity of the anti-NK-1 receptor antibody [omission of the primary antibody (immunohistochemistry and western blot analysis), preabsorption of the primary antibody with the corresponding synthetic peptide (immunohistochemistry), the use of human gliomas as positive controls (immunohistochemistry and western blot analysis)]. In all cases, the results confirmed the specificity of the anti-NK-1 receptor antibody used in this study. This specificity was also confirmed by the results found in BC samples, since in the same BC sample we observed cells expressing as well as not expressing NK-1 receptors.

We also demonstrate the presence of isoforms of different molecular weight in BC cell lines. This is in agreement with the results of previous studies in which the presence of these isoforms was reported in human neuroblastoma, glioma, retinoblastoma, pancreatic, larynx, colon and gastric carcinoma cell lines $(18,32,35-37)$. Currently, the functional roles of the different isoforms of the NK-1 receptor observed in human cancer cell lines are unknown. In any case, it should be recalled that the different human tumor cell lines mentioned above express the same isoforms of the NK-1 receptor.

Another important result found in our study is the involvement of the NK-1 receptor in the viability of BC cell lines. After eliminating NK-1 receptors by a knockdown method, we observed that this receptor plays a crucial role in the viability of BC cells, as has been reported previously in human melanoma and acute lymphoblastic leukemia cell lines when using the same methodology $(16,23)$. This means that in the future the NK-1 receptor could well be a target for the development of new strategies for the treatment of cancer.

In this study, we also demonstrate that $\mathrm{BC}$ cell lines express mRNA for the NK-1 receptor and that the expression of the NK-1 receptor is higher in BC cell lines (BT-474, MT-3, MCF-7 and MDA-MB-468) than in normal breast epithelial cell lines (MCF-10A and MCF-12A). This is in agreement with previous studies. In this sense, the expression of preprotachykinin-I and NK-1 receptors has been reported in both human BC cells (BT-474, MDA-MB-330, T47D, ZR-75-30, DU-4475, BT-483, 184B5) and breast biopsies (9). The authors found that NK-1 receptor and preprotachykinin-I mRNA levels in BC cells were significantly increased in comparison with normal cells and that NK-1 receptor and preprotachykinin-I expression was increased in malignant tissues, since in benign tissues NK-1 receptor and preprotachykinin-I mRNA were not detected (9). The data provided by Singh et al (9) and those reported here in $\mathrm{BC}$ are in agreement with other studies carried out in other cancer cell lines. Thus, it is known that NK-1 receptors are overexpressed in primary glioblastoma, retinoblastoma, and larynx, pancreatic, gastric and colon carcinomas $(13,15,36-38)$ and that tumor samples from patients with advanced tumor stages exhibit significantly higher NK-1 receptor levels (13). Our data are also in agreement with the study carried out by
Bigioni et al (11), in which the expression of mRNA for the NK-1 receptor in MDA-MB-231 tumor cells was demonstrated.

Moreover, it is known that there are two naturally occurring forms of the NK-1 receptor: the full-length and the truncated forms. It has been recently demonstrated that the expression of the full-length NK-1 receptor is inversely associated with proliferation, invasiveness and metastasis of MDA-MB-231 cells and that overexpression of the truncated NK-1 receptor promotes tumor progression and metastasis in human breast cancer (39).

The data reported above suggest that the NK-1 receptor should be considered as a target in the treatment of $\mathrm{BC}$ and that by using immunohistochemical methods NK-1 receptor visualization should facilitate the identification of tumors with a sufficient NK-1 receptor overexpression for diagnostic and therapeutic intervention (e.g., using NK-1 receptor antagonists).

SP and BC cell proliferation and migration. In the four BC cell lines studied we show that SP exerts a mitogenic action and that SP is located in the nucleus and in the cytoplasm of cells in BC samples. Our results are in agreement with a previous study in which the production of SP by BC cells was reported (9) as well as with other studies in which SP or $\left[\mathrm{Sar}^{9}, \operatorname{Met}\left(\mathrm{O}_{2}\right)^{11}\right] \mathrm{SP}$, respectively, induced the proliferation of MDA-MB-231 and T47D BC cells $(10,11)$. These data are also in agreement with the mitogenic action exerted by SP on other human cancer cell lines $(3,14,18,23,30,35,36,40,41)$. Moreover, it has been suggested that SP acts as an autocrine signal essential for BC cell survival (24). All these findings suggest that the peptide SP should act as a universal mitogenic agent in tumor cells. It should also be remarked that SP is widely distributed in the central and peripheral nervous systems and this means that a new mechanism for the regulation of local tumor activity by peripheral sensory nerves containing SP, through the NK-1 receptor, should be taken into consideration. Moreover, it has been demonstrated that SP protects against cell death $(2,3,42)$; that the inhibition of SP with antibodies impairs BC cell proliferation (24); and that psychological factors are also involved in the development and progression of BC (43). It is known that SP is expressed in the limbic system, this system being involved in emotional behavior and hence this system could regulate both the progression of cancer and the immune system, since all the above data indicate that emotional behavior (e.g., depression) (44) and BC might be related through alterations in the $\mathrm{SP} / \mathrm{NK} 1$ receptor system.

We report here for the first time the presence of SP in the nucleus of BC cells. This is in agreement with other studies, since SP has been reported in the nucleus of tumor cells in keratocystic odontogenic tumors, oral squamous cell carcinoma and larynx carcinoma tissues, and human normal placenta $(15,31,34,45)$. In all cases, the functional significance of SP in the nucleus of tumor cells is currently unknown and in the future a possible genetic neuromodulatory action of the peptide should be investigated (45). It should be remarked that we observed SP-immunoreactivity in the nucleus of smooth muscle cells and in the endothelial cells of the small- and medium-caliber blood vessels located in the peritumor area and that immunoreactivity for NK-1 receptors was also observed in this area. This suggests that the SP detected in 
the peritumor area could be involved in the growth of capillary vessels and, if this were the case, then endothelial cell proliferation could be blocked specifically by NK-1 receptor antagonists (27), since it has been reported that SP induces the growth of capillary vessels in vivo and the proliferation of cultured endothelial cells in vitro $(25,28)$. It has been reported that an NK-1 receptor antagonist inhibited neoangiogenesis in tumor mass (46). Our findings are in agreement with previous studies, since in a large majority of the tumors investigated, NK-1 receptors have been found in intra- and peritumor blood vessels $(10,23)$. Moreover, it is known that endostatin (an inhibitor of angiogenesis) inhibited the growth of breast cancer and potentiated the antitumor effect of radiotherapy via alteration of the levels of SP (47). The amount of SP increased within $72 \mathrm{~h}$ after radiotherapy, but this increase was inhibited when endostatin and radiotherapy were applied in combination (47).

$\mathrm{BC}$ is the highest cause of cancer-related death in females and although the reasons for such deaths may be varied, most patients succumb to bone metastasis $(12,48,49)$. Tumor cell migration is a crucial requirement for the development of metastasis and cancer progression. It has been suggested that peptides promote bone marrow metastasis of BC cells (50). Thus, it has been reported that SP induces the migration of tumor cells to specific organs by binding to NK-1 receptors in cancer cells, where it can be blocked by NK-1 receptor antagonists (e.g., L-733,060) (26,51). It has been reported that the migration of MDA-MB-468 BC cells induced by SP was blocked by using an NK-1 receptor antagonist (26). Moreover, it is known that activation of the NK-1 receptor by SP induces a rapid change in cellular shape in HEK-293 cells, including blebbing, this being a consequence of the Rho-activated ROCK system, leading to an increase in the phosphorylation of the myosin regulatory light chain (MLC) (52). Membrane blebbing is important in cell movement, cell spreading, and in cancer cell invasion $(51,52)$. All these data suggest that the SP/NK-1 receptor system could play an important role in the development of invasion and metastasis and that NK-1 receptor antagonists could block the migration of tumor cells. Thus, in order to prevent BC growth and spreading, the administration of the drug aprepitant to patients during the perioperative period has been suggested (5).

$N K-1$ receptor antagonists and $B C$. We demonstrate for the first time that the NK-1 receptor antagonists L-732,138 and the drug aprepitant totally inhibit the growth of the $\mathrm{BC}$ cell lines studied and that these antagonists induce the death of BC cells by apoptosis. Our results are in consonance with previous studies, in which the NK-1 receptor antagonist SR-140,333 reduced the growth of the T47D cell line and induced apoptosis in this BC cell line (10); in which the NK-1 receptor antagonist CP-96,345 reduced BC cell (T47D, BT-474, ZR-75-30, MDA-MB330, DU4475) proliferation (9); in which the NK-1 receptor antagonist L-733,060 decreased cell proliferation in $\mathrm{BC}$ cells (24); and in which the NK-1 receptor antagonist MEN-11467 reduced the proliferation of the MDA-MB-231 cell line (11). However, it should be remarked that these four studies using different NK-1 receptor antagonists did not show a total inhibition of $\mathrm{BC}$ cell proliferation, as reported here. It should also be noted that Singh et al (9) administered a low dose $(1 \mathrm{nM})$ of CP-96,345, whereas we used $\mu \mathrm{M}$ concentrations of L-733,060, L-732,138 or aprepitant. Thus, using a higher dose we observed that all BC cells died, whereas Singh et al (9) did not, probably due to the lower dose used. All these data are also in agreement with a study carried out in vivo in which it was demonstrated that the NK-1 receptor MEN-11,467 controls the growth of BC (11). Moreover, our results are in agreement with findings showing that NK-1 receptor antagonists (e.g., aprepitant, L-733,060) have antitumor activity against other human cancer cell lines, such as neuroblastoma, glioma, melanoma, retinoblastoma, pancreas, larynx, colon and gastric carcinomas, this antitumor activity being due to apoptosis of tumor cells (18,20,23,30,35-37). Additionally, in cell lines as different as those mentioned above the same NK1 receptor antagonists elicited growth inhibition. This observation suggests the possibility of a common mechanism for cancer cell proliferation mediated by SP and NK1 receptors. In addition, we have demonstrated the safety of the NK-1 receptor antagonist aprepitant against MCF-10A and MCF-12A human breast epithelial cell lines, since in both cell lines the $\mathrm{IC}_{50}$ was $>90 \mu \mathrm{M}$, three times higher than the $\mathrm{IC}_{50}$ for the $\mathrm{BC}$ cells studied here and higher than the $\mathrm{IC}_{100}$ for such tumor cells (Table II).

The BC cell death observed here was due to a specific toxic effect of the NK-1 receptor antagonists used and not to any non-specific action of these drugs, since in the competition experiments carried out here exogenous SP cell proliferation was partially reverted by administration of the three NK-1 receptor antagonists studied. This demonstrates the specificity of NK-1 receptor blockade in human BC cell lines by these antagonists. This observation is in agreement with those reported in previous studies in other human cancer cell lines (e.g., retinoblastoma, and melanoma) $(23,26,37)$. As has been suggested previously for other tumor cells, it seems that in BC cells the blockade of NK-1 receptors by NK-1 receptor antagonists could inhibit both DNA synthesis and cell proliferation through the mitogen-activated protein kinase (MAPK) pathway $(14,24)$. NK-1 receptor antagonists could also inhibit the formation of a $\beta$-arrestin-containing complex that allows the nuclear translocation of ERK1/2, inhibiting proliferation and inducing apoptosis (53). NK-1 receptor antagonists decrease the basal phosphorylation of Akt, indicating the presence of a constitutively active form of NK-1 receptor for eliciting apoptosis in tumor cells and also for causing the cleavage of caspase-3 and proteolysis of poly(ADP-ribose) polymerase (54). The latter finding is in agreement with our results, since we have shown that aprepitant increased both the cleaved PARP and caspase- 3 forms, indicating the activation of apoptosis. The death of tumor cells occurs after activation of the apoptotic machinery, and this means that the induction of apoptosis represents an appropriate method for cancer treatment.

Tumor cells need to set up strategies to neutralize the multiple pathways leading to cell death, and it may be proposed that at least one of the most important is the activation and/or an increase in the phenotypic expression of the NK-1 receptor (19). Increased NK-1 receptor expression renders tumor cells highly dependent on the SP stimulus, a potent mitotic signal. The increased SP-mediated mitogenic signal could counteract the different death-signal pathways activated in each tumor cell 
due to its own genetic damage, oncogene activation, etc. Lack of this mitogenic signal after the receptor has been blocked with the NK-1 receptor antagonist could render the balance inside the cell favourable to apoptotic/death signals, leading to cell death. Thus, a number of different death signals are overridden by the SP-mediated mitotic stimulus; by cutting the potent mitotic signal induced by SP, NK-1 receptor antagonists leave the cell alone with its death load or at least render the balance between life and death signals favourable to the latter (19). This hypothesis is in agreement with a previous study in which the 'oncogenic addiction' of BC cell lines to NK-1 signalling has been suggested (24).

It is known that HER2-positive cells indicate the presence of a protein called human epidermal growth factor receptor 2 (HER2), which promotes the growth of cancer cells. HER2positive $\mathrm{BC}$ tends to be more aggressive than other types of BC (24). Moreover, it has been reported that SP contributes to persistent HER2 activation driving malignant progression and drug resistance in breast cancer (55). Here we report that NK-1 receptor antagonists exert an antitumor effect against BC cell lines overexpressing (BT-474) (HER2-positive), or not (MCF-7) (HER2-negative), the HER2/neu gene. In approximately 1 out of all $5 \mathrm{BC}$ cases, cancer cells make an excess of HER 2 due to a gene mutation. This gene mutation and the elevated levels of HER2 that it causes can occur in many types of cancer; not only in BC. HER2-positive cells are less responsive to hormone treatment, but treatments that specifically target HER2 are very effective (24).

In conclusion, we performed an in-depth study of the involvement of the SP/NK-1 receptor system in BC. Our findings suggest that the NK-1 receptor is a candidate target in the treatment of $\mathrm{BC}$ and that $\mathrm{NK}-1$ receptor antagonists (e.g., aprepitant) could be novel, promising antitumor drugs in BC therapy, since they could exert an antitumor action through three mechanisms: i) an antiproliferative effect, due to the inhibition of tumor cell growth, inducing cell death by apoptosis; ii) an inhibition of angiogenesis in the tumor mass; and iii) an inhibition of tumor cell migration (invasion and metastasis). In the future, the antitumor action of aprepitant (already available and widely used in clinical practice) should be tested in human clinical trials, since the safety and tolerability of this drug has already been demonstrated. The findings described here are not exclusive to $\mathrm{BC}$, since there are sufficient data to suggest that a common mechanism for cancer cell proliferation mediated by SP and the NK-1 receptor occurs and that NK-1 receptor antagonists are broad spectrum antineoplastic drugs. This should be confirmed definitively in the coming years.

\section{Acknowledgements}

The authors wish to thank Dr José Palacios for providing lung cancer samples, and Dr Marisa Rosso, Mr. Manuel Sánchez and Mr. Francisco Jesus Fuentes for technical assistance and Mr. Nicholas Skinner for supervising the English text. This study was supported by the Consejería de Innovacion, Ciencia y Empresa of the Regional Government of Andalucía (CTS-2247, Spain), by the Fondo de Investigación Sanitaria, by a grant from the Fundación Cellex, and by Redes Temáticas de Investigación en Cáncer (RTICC, RD07/0020/2014). This study was carried out in part at the Esther Koplowitz Centre, Barcelona (Spain). Conflict of interest: USPTO Application no. 20090012086 'Use of non-peptidic NK-1 receptor antagonists for the production of apoptosis in tumor cells' (Miguel Muñoz). ES patent Application no. 200801071 'Use of monoclonal antibodies against substance $\mathrm{P}$ to treat cancer' (Vanessa Almendro).

\section{References}

1. Ahmedin J, Freddie B, Melissa M, Jacques F, Elizabeth W and David F: Global cancer statistics. CA Cancer J Clin 61: 69-90, 2011.

2. Muñoz M, Rosso M and Coveñas R: The NK-1 receptor: a new target in cancer therapy. Curr Drug Targets 12: 909-921, 2011.

3. Muñoz M, Rosso M and Coveñas R: A new frontier in the treatment of cancer: NK-1 receptor antagonists. Curr Med Chem 17: 504-516, 2010.

4. Muñoz M and Coveñas R: NK-1 receptor antagonists: a new paradigm in pharmacological therapy. Curr Med Chem 17: 504-513, 2011.

5. Muñoz M, Rosso M, Casinello F and Coveñas R: Paravertebral anesthesia: how substance P and the NK-1 receptor could be involved in regional block and breast cancer recurrence. Breast Cancer Res Treat 122: 601-603, 2010.

6. Mancino M, Ametller E, Gascón P and Almendro V: The neuronal influence on tumor progression. Biochim Biophys Acta 1816: 105-118, 2011.

7. Muñoz M, Berger M, Rosso M, et al: Antitumor activity of neurokinin-1 receptor antagonists in MG-63 human osteosarcoma xenografts. Int J Oncol 44: 137-146, 2014.

8. Berger M, Neth O, Ilmer M, et al: Hepatoblastoma cells express truncated neurokinin-1 and can be growth inhibited by aprepitant in vitro and in vivo. J Hepatol 60: 985-994, 2014.

9. Singh D, Joshi DD, Hameed M, et al: Increased expression of preprotachykinin-I and neurokinin receptors in human breast cancer cells: implications for bone marrow metastasis. Proc Natl Acad Sci USA 97: 388-393, 2000.

10. Huang WQ, Wang JG, Chen L, Wei HJ and Chen H: SR-140,333 counteracts NK-1 mediated cell proliferation in human breast cancer cell line T47D. J Exp Clin Cancer Res 29: 55-62, 2010.

11. Bigioni M, Benzo A, Irrissuto C, Maggi CA and Goso C: Role of NK-1 and NK-2 tachykinin receptor antagonism on the growth of human breast carcinoma cell line MDA-MB-231. Anticancer Drugs 16: 1083-1089, 2005.

12. Patel HJ, Ramkissoon SH, Patel PS and Rameshwar P: Transformation of breast cells by truncated neurokinin-1 receptor is secondary to activation by preprotachykinin-A peptides. Proc Natl Acad Sci USA 102: 17436-17441, 2005.

13. Friess $\mathrm{H}, \mathrm{Zhu} \mathrm{Z}$, Liard V, et al: Neurokinin-1 receptor expression and its potential effects on tumor growth in human pancreatic cancer. Lab Invest 83: 731-742, 2003.

14. Luo W, Sharif TR and Sharif M: Substance P-induced mitogenesis in human astrocytoma cells correlates with activation of the mitogen-activated protein kinase signaling pathway. Cancer Res 56: 4983-4991, 1996.

15. Esteban F, González-Moles MA, Castro D, et al: Expression of substance $\mathrm{P}$ and neurokinin-1-receptor in laryngeal cancer: linking chronic inflammation to cancer promotion and progression. Histopathology 54: 258-260, 2009.

16. Muñoz M, González-Ortega A and Coveñas R: The NK-1 receptor is expressed in human leukemia and is involved in the antitumor action of aprepitant and other NK-1 receptor antagonists on acute lymphoblastic leukemia cell lines. Invest New Drugs 30: 529-540, 2010.

17. Muñoz M, Pérez A, Rosso M, Zamarriego C and Rosso R: Antitumoural action of NK1 receptor antagonist L-733,060 on human melanoma cell lines. Melanoma Res 14: 183-188, 2004.

18. Muñoz M, Rosso M, Aguilar FJ, et al: NK-1 receptor antagonists induce apoptosis and counteract substance P-related mitogenesis in human laryngeal cancer cell line HEp-2. Invest New Drugs 26: 111-118, 2008.

19. Esteban F, Muñoz M, González-Moles MA and Rosso M: A role for substance $\mathrm{P}$ in cancer promotion and progression: a mechanism to counteract intracellular death signals following oncogene activation or DNA damage. Cancer Metast Rev 25: $137-145,2006$. 
20. Muñoz M and Rosso M: The NK-1 receptor antagonist aprepitant as a broad spectrum antitumor drug. Invest New Drugs 28: 187-193, 2010

21. Palma C, Bigioni M, Irrissuto C, et al: Anti-tumour activity of tachykinin NK1 receptor antagonists on human glioma U373 MG xenograft. Br J Cancer 82: 480-487, 2000.

22. Palma C, Nardelli F, Manzini S and Maggi CA: Substance P activates responses correlated with tumour growth in human glioma cell lines bearing tachykinin NK1 receptors. Br J Cancer 79: 236-243, 1999

23. Muñoz M, Rosso M, Robles-Frías MJ, et al: The NK-1 receptor is expressed in human melanoma and is involved in the antitumor action of the NK-1 receptor antagonist aprepitant on melanoma cell lines. Lab Invest 90: 1259-1269, 2010.

24. Mayordomo C, García-Recio S, Ametller E, et al: Targeting of substance $\mathrm{P}$ induces cancer cell death and decreases the steady state of EGFR and Her2. J Cell Physiol 227: 1358-1366, 2011.

25. Ziche M, Morbidelli L, Pacini M, et al: Substance P stimulates neovascularization in vivo and proliferation of cultured endothelial cells. Microvasc Res 40: 264-278, 1990.

26. Lang K, Drell TL, Lindecke A, et al: Induction of a metastatogenic tumor cell type by neurotransmitters and its pharmacological inhibition by established drugs. Int J Cancer 112: 231-238, 2004.

27. Fan TP, Hu DE, Guard S, Gresham GA and Watling KJ: Stimulation of angiogenesis by substance $\mathrm{P}$ an interleukin-1 in the rat and its inhibition by NK1 or interleukin-1 receptor antagonists. Br J Pharmacol 110: 43-49, 1993.

28. Seegers HC, Hood VC, Kidd BL, Cruwys SC and Walsh DA: Enhancement of angiogenesis by endogenous substance $P$ release and neurokinin-1 receptors during neurogenic inflammation. J Pharmacol Exp Ther 306: 8-12, 2003.

29. Muñoz M, Bernabeu-Wittel J and Coveñas R: NK-1 as a melanoma target. Expert Opin Ther Targets 15: 889-897, 2011.

30. Muñoz M, Rosso M, Pérez A, et al: The NK-1 receptor is involved in the antitumoural action of L-733,060 and the mitogenic action of substance $\mathrm{P}$ on neuroblastoma and glioma cell lines. Neuropeptides 39: 427-432, 2005.

31. Brener S, González-Moles MA, Tostes D, et al: A role for the substance P/NK-1 receptor complex in cell proliferation in oral squamous cell carcinoma. Anticancer Res 29: 2323-2329, 2009.

32. Moneo V, Serelde BG, Leal JFM, et al: Levels of p2 $7^{\text {kipl }}$ determine Aplidin sensitivity. Mol Cancer Ther 6: 1310-1316, 2007.

33. Tansky MF, Pothoulakis C and Leeman SE: Functional consequences of alteration of $\mathrm{N}$-linked glycosylation sites on the neurokinin-1 receptor. Proc Natl Acad Sci USA 104: 10691-10696, 2007.

34. González Moles MA, Mosqueda-Taylor A, Esteban F, et al: Cell proliferation associated with actions of the SP/NK-1 receptor complex in keratocystic odontogenic tumours. Oral Oncol 44: 1127-1133, 2008.

35. Muñoz M, Rosso M and Coveñas R: The NK-1 receptor is involved in the antitumoural action of L-733,060 and in the mitogenic action of substance $\mathrm{P}$ on human pancreatic cancer cell lines. Lett Drug Des Discov 3: 323-329, 2006.

36. Rosso M, Robles-Frías MJ, Coveñas R, Salinas-Martín MV and Muñoz M: The NK-1 receptor is involved in the antitumor action of L-733,060 and in the mitogenic action of substance $\mathrm{P}$ on human gastrointestinal cancer cell lines. Tumor Biol 29: 245-254, 2008.

37. Muñoz M, Rosso M, Coveñas R, et al: Neurokinin-1 receptors located in human retinoblastoma cell lines: antitumor action of its antagonists, L-732,138. Invest Ophthalmol Vis Sci 48: 2775-2781, 2007.
38. Hennig IM, Laissue JA, Horisberger U and Reubi JC: Substance-P receptors in human primary neoplasms: tumor and vascular localization. Int J Cancer 61: 786-792, 1995.

39. Zhou Y, Zhao L, Xiong T, et al: Roles of full-length and truncated neurokinin-1 receptors on tumor progression and distant metastasis in human breast cancer. Breast Cancer Res Treat 140: 49-61, 2013.

40. Muñoz M, Rosso M, Pérez A, et al: Antitumor action of the neurokinin-1-receptor antagonist L-733,060 and mitogenic action of substance $\mathrm{P}$ on human retinoblastoma cell lines. Invest Ophthalmol Vis Sci 46: 2567-2570, 2005.

41. Muñoz M, Rosso M, González-Ortega A and Coveñas R: The NK-1 receptor antagonist L-732,138 induces apoptosis and counteracts substance P-related mitogenesis in human melanoma cell lines. Cancers 2: 611-623, 2010.

42. Dimri R, Sharabi Y and Shoham J: Specific inhibition of glucocorticoid thymocyte apoptosis by substance P. J Immunol 164: 2479-2486, 2000.

43. Hilakivi-Clarke L, Rowland J, Clarke R and Lippman ME: Psychosocial factors in the development and progression of breast cancer. Breast Cancer Res Treat 29: 141-160, 1994.

44. De Vane CL: Substance P: a new era, a new role. Pharmacotherapy 21: 1061-1069, 2001

45. Muñoz M, Pavón A, Rosso M, et al: Immunolocalization of NK-1 receptor and substance $\mathrm{P}$ in human normal placenta. Placenta 31 : 649-651, 2010.

46. Guha S, Eibl G, Kisfalvi K, et al: Broad-spectrum G proteincoupled receptor antagonist, [D-Arg1,DTrp5,7,9,Leu11]SP: a dual inhibitor of growth and angiogenesis in pancreatic cancer. Cancer Res 65: 2738-2745, 2005.

47. Arslan Aydemir E, Simsek Oz E, Fidan Korcum A and Fiskin K: Endostatin enhances radioresponse in breast cancer cells via alteration of substance P levels. Oncol Lett 2: 879-886, 2011.

48. Jemal A, Murray T, Samuels A, et al: Cancer statistics, 2003. CA Cancer J Clin 53: 5-26, 2003.

49. Mundy GR: Metastasis to bone: causes, consequences and therapeutic opportunities. Nat Rev Cancer 2: 584-593, 2002.

50. Rao G, Patel GS, Idler SP, et al: Facilitating role of preprotachykinin-I gene in the integration of breast cancer cells within the stromal compartment of the bone marrow: a model of early cancer progression. Cancer Res 64: 2874-2881, 2004.

51. Meshki J, Douglas SD, Lai JP, et al: Neurokinin 1 receptor mediates membrane blebbing in HEK293 cells through a Rho/ Rho-associated coiled-coil kinasedependent mechanism. J Biol Chem 284: 9280-9289, 2009.

52. Fackler OT and Grosse R: Cell motility through plasma membrane blebbing. J Cell Biol 181: 879-884, 2008.

53. DeFea KA, Vaughn ZD, O'Bryan EM, et al: The proliferative and antiapoptotic effects of substance $\mathrm{P}$ are facilitated by formation of a beta-arrestin-dependent scaffolding complex. Proc Natl Acad Sci USA 97: 11086-11091, 2000.

54. Akazawa T, Kwatra SG, Goldsmith LE, et al: A constitutively active form of neurokinin 1 receptor and neurokinin 1 receptormediated apoptosis in glioblastomas. J Neurochem 109: 1079-1086, 2009

55. García-Recio S, Fuster G, Fernández-Nogueira P, et al: Substance $\mathrm{P}$ autocrine signaling contributes to persistent HER2 activation that drives malignant progression and drug resistance in breast cancer. Cancer Res 73: 6424-6434, 2013. 